NBER WORKING PAPER SERIES

\title{
DAILY NEEDS, INCOME TARGETS AND LABOR SUPPLY: EVIDENCE FROM KENYA
}

\author{
Pascaline Dupas \\ Jonathan Robinson \\ Working Paper 19264 \\ http://www.nber.org/papers/w19264
NATIONAL BUREAU OF ECONOMIC RESEARCH
1050 Massachusetts Avenue
Cambridge, MA 02138 \\ July 2013
}

The study protocol for this research was approved by the IRBs of UCLA, UCSC, and IPA Kenya. We thank Sandro Ambuehl, Christine Exley, Tim Halliday, Supreet Kaur, Sendhil Mullainathan, Muriel Niederle, Alan Spearot, Eric Verhoogen, Andrew Zeitlin and participants at various seminars for helpful comments. We are grateful to IPA Kenya for administrative assistance coordinating the project, to Moses Barasa and Sarah Walker for coordinating field activities, and to Sindy Li for research assistance. All errors are our own. The views expressed herein are those of the authors and do not necessarily reflect the views of the National Bureau of Economic Research.

NBER working papers are circulated for discussion and comment purposes. They have not been peerreviewed or been subject to the review by the NBER Board of Directors that accompanies official NBER publications.

(C) 2013 by Pascaline Dupas and Jonathan Robinson. All rights reserved. Short sections of text, not to exceed two paragraphs, may be quoted without explicit permission provided that full credit, including (C) notice, is given to the source. 
Daily Needs, Income Targets and Labor Supply: Evidence from Kenya

Pascaline Dupas and Jonathan Robinson

NBER Working Paper No. 19264

July 2013

JEL No. C93,D12,J22

\begin{abstract}
Many studies suggest that daily income earners behave as if they have daily income targets. Less work has examined the determinants of the targets themselves. Using data on labor supply, shocks, and selfreported cash needs from 257 bicycle taxi drivers in Western Kenya, we provide evidence that many individuals treat their daily cash need as the day's target. We conjecture that in a physically demanding job, workers may have an incentive to quit early and so set a personal rule of "earning enough for the day's need" as an internal commitment device to provide effort. This heuristic is more common among less educated workers and has substantial welfare costs: greater variance in hours worked is associated with worse health, and we estimate that workers would earn 5\% more by working a set number of hours each day (more if their wage elasticity were positive).
\end{abstract}

Pascaline Dupas

Department of Economics

Stanford University

579 Serra Mall

Stanford, CA 94305-6072

and NBER

pdupas@stanford.edu

Jonathan Robinson

Department of Economics

University of California, Santa Cruz

457 Engineering 2

Santa Cruz, CA 95064

and NBER

jmrtwo@ucsc.edu 


\section{Introduction}

The majority of people in developing countries are self-employed and so can set their own work hours. While such flexibility has obvious advantages, it also has the fundamental disadvantage of being susceptible to self-control issues: without a fixed hours schedule, it may be tempting for a worker to quit earlier in the day than he had planned (especially in a physically demanding occupation). As shown in recent work with Indian data processors (Kaur, Kremer and Mullainathan, 2010, 2013) and Berkeley undergraduates (Augenblick, Niederle and Sprenger, 2013), individuals with such time-inconsistent preferences over effort will demand external constraints to help them meet work targets.1. However, such external commitment devices are not typically available outside of formal work arrangements or a laboratory setting. How do self-employed workers in low-skill, repetitive occupations motivate themselves to work hard day after day?

This paper studies the labor supply decisions of one specific group of workers in a physically challenging occupation: Kenyan bicycle taxi drivers. These workers (all of whom are men) carry passengers or goods on the back of their bicycles, and many report being in poor health, so quitting early may be tempting. Using a novel dataset collected from daily passenger-level logbooks kept by 257 drivers over approximately 2 months on average, combined with experimentally created non-labor income shocks, we establish four empirical facts about their daily labor supply decisions, and discuss what behavioral models can jointly explain all four facts.

First, while the within-driver variance in daily hours worked is large (the within-driver standard deviation of hours is 2, compared to mean hours of 9), the variation does not appear to be consistent with intertemporal optimization: conditional on working, we find a negative wage elasticity of hours worked, a result which is consistent with Camerer et al. (1997) and others. However, we find that hours are positively correlated with the individual's reported "cash need" for the day. These reported cash needs include funds needed to deal with unexpected shocks (e.g. a sick family member needing medical treatment, or a request to help with funeral expenses), but also expected events (e.g. school fees or a weekly savings club payment coming due).

Second, within a given day, individuals are more likely to quit immediately after earning enough to deal with their need: our within-day, within-driver passenger-level data shows that the quitting hazard increases discontinuously once workers earn enough to meet their need. Since cash needs are largely uncorrelated with the wage rate, this behavior explains

\footnotetext{
${ }^{1}$ In particular, Kaur et al. (2010, 2013) shows that data entry operators voluntarily enter into employment contracts which penalize them for not meeting daily work targets.
} 
the negative wage elasticity.

Third, labor supply in the days leading to a high cash need, even if expected, does not respond to the upcoming need. This result is supportive of the quitting behavior: since people procrastinate until the cash is needed, the need becomes binding.

Fourth, the experiment provided respondents with random, unexpected cash payments on random days. We use this experimental variation to estimate the responsiveness of labor supply to positive non-labor income shocks. We find no effect of the payments on daily labor supply, and in particular, no effect on the likelihood of quitting once labor income has reached the stated cash need amount.

Why can't Kenyan bicycle taxi drivers better smooth their labor supply, working past their cash needs on low-need days and dissaving on high-need days? A likely explanation is that they are "target earners", as first proposed by Camerer et al. (1997) with respect to New York City cab drivers and investigated in a number of subsequent studies with various types of daily income earners. ${ }^{2}$ Target earners anchor around a daily income target; once this target is set, workers are loss averse over it and are therefore more likely to quit after reaching the target. Our evidence is consistent with bicycle-taxi drivers in Kenya having a target that varies daily with their cash needs. The fact that unexpected unearned income shocks (such as the random cash payouts during our study) do not affect their labor supply strongly suggests that this daily target is over labor income, however, and not total income.

Why would workers have labor income targets? Camerer et al. (1997) discuss how income targets could be an internal commitment device to provide effort: setting a target before starting work in the morning may be a way to avoid succumbing to the temptation of quitting early. How though are the targets set? This is a fundamental issue when thinking about the potential for income-targeting to mitigate the tendency to put off effort. If workers can endogenously choose a high target for themselves every day, then self-control problems can easily be overcome. But if, as formalized by Köszegi and Rabin (2006), targets need to be based on rational expectations of effort and earnings to be binding, then self-control issues may remain important.

Our evidence suggests that targets are based in part on exogenous cash needs, and in part on rational forecasts of expected earnings (in accord with the discussion in Köszegi and Rabin 2006 and empirical work by Crawford and Meng 2011 and Abeler et al. 2011). We also find that bike-taxi drivers are not able to set and commit to a high target in expectation of a large cash need coming up in the future - they do not work more even on the day before an expectedly high cash need. Instead, only the current day's needs affect the target.

\footnotetext{
${ }^{2}$ See Chou 2002, Farber 2005, 2008, Crawford and Meng 2011 and Doran 2012 on taxi drivers; Fehr and Goette 2007 on bicycle messengers; and Chang and Gross 2012 on fruit packers.
} 
Overall, our conjecture is that workers in our sample procrastinate on earning enough to cope with cash needs until they can no longer put the need off. To overcome the temptation to put off work forever, they treat earning enough for the immediate needs as a kind of personal rule - an internal commitment device. Their success in following this rule may come from reference-dependent preferences, as in Köszegi and Rabin (2006), or because deviating from the rule would create a precedent for future days, as in Ainslie (1992) and Benabou and Tirole (2004). We also conjecture that this rule is over labor income, rather than labor hours, for two possible reasons. First, working a set number of hours does not prevent shirking on the job - e.g. not making enough effort to find customers or taking long breaks. Second, cash targets are more easily enforceable by someone else, for example the spouse. Bike drivers that leave their house in the morning and tell their wife: "I won't come home until I have the $100 \mathrm{Ksh}$ we need to pay the school fees" are committing more strongly than those who say "I will work for 8 hours," since some of the 8 hours could be spent idling.

What are the welfare consequences of this heuristic? Since the workers in our sample display a negative wage elasticity, they could earn more by reallocating labor supply intertemporally from low wage days to high wage days. Estimating the lost income is difficult, however, since we do not know what the counterfactual elasticity should be. We therefore conservatively estimate how much extra income workers would make under (1) a fixed hours rule and (2) assuming a 0.15 elasticity as in Chetty (2012). Similar to other studies, we estimate modest, though not insubstantial, mean increases in income of 5-8\% (this amount would of course be larger if wage elasticities were larger) $]^{3}$ Another implication of income targeting is that workers work some very long days and some very short days. If work effort has a negative impact on health and daily effort costs are convex, then workers will be in worse health by working long days. We find some speculative evidence consistent with this: workers with greater variance in hours worked over our study period are in worse health at endline (conditional on baseline health status).

While our explanation for the labor supply patterns we observe is ultimately a conjecture, we provide evidence against some alternatives. The main set of alternatives are models of labor supply under subsistence constraints; i.e. that people use bike taxiing to generate cash to meet immediate subsistence needs, but then quit immediately after reaching the need. This could be because (1) the returns to another occupation have higher returns but delayed payouts; (2) people are unable to save money past their immediate consumption needs; or (3) effort costs are so high that it is optimal to quit immediately at the need. The main evidence

\footnotetext{
${ }^{3}$ For example, Camerer et al. (1997) estimate that a fixed hours rule would increase income by $5 \%$ among New York City cabdrivers. Kaur et al. (2013) estimate a treatment on the treated effect of a $6 \%$ increase in productivity from providing workers with commitment devices.
} 
against any of these possibilities are the random cash payouts: each of these models would predict quitting on those days. We also provide further evidence by performing subgroup analyses and find little support for heterogeneity along these dimensions.

Our paper contributes to the literature in several ways. First, we contribute to the literature on income targeting, and provide the first empirical evidence that income targeting among daily income workers outside of the lab is over earned income and not total income, suggesting that income targeting may indeed be, as suggested by Camerer et al. (1997), a form of mental accounting that acts as an internal commitment device. Second, we contribute to the literature on self-control at work, which as highlighted by Kaur et al. (2013), is a much different problem than self-control over consumption or income. Third, our paper contributes to the literature on simple heuristics, personal rules or rules of thumb that people may use to deal with certain biases (Ainslie 1992; Bénabou and Tirole, 2004; Benartzi and Thaler, 2007; Thaler and Sunstein, 2008). Finally, since we have data on labor supply both within and across days, our results are also related to studies which focus on the extensive margin of labor supply, including Oettinger (1999) on stadium vendors in the US, Goldberg (2012) on day laborers in Malawi, and Giné et al. (2009) on fishermen in India.4 Lastly, while this study focuses specifically on one sample of workers in one part of Kenya, the general patten of results may generalize to a relatively broad subset of workers in the developing world because many people in developing countries are self-employed in low-skilled but physically demanding occupations.

The layout of the paper is as follows. Section 2 lays out a motivating framework and Section 3 discusses the data. Section 4 presents our main results, while Section 5 discuss interpretations of the pattern of results. Section 6 discusses welfare implications, and Section 7 concludes.

\section{Conceptual Framework}

The basic framework has two components. First, workers set targets. Second, conditional on the target, workers apply effort. In principle, the targets could be set in any number of ways. However, as we will show in the empirical section, the targets appear to be driven largely by cash needs, both expected and unexpected.

The fact that workers set daily targets at all, even though one day's income is a trivial fraction of lifetime income, is likely due to the phenomenon of "narrow bracketing." The

\footnotetext{
${ }^{4}$ Our results are also related to Hossain and List (2012), who conduct an experiment with a Chinese high-tech manufacturing firm and find that conditional incentives framed as losses have bigger effect than if they are framed as gains.
} 
targets can be interpreted in two ways. First, as developed by Camerer et al. (1997), Köszegi and Rabin (2006) and Crawford and Meng (2011), workers may have reference-dependent preferences, and the income target may be a reference point over which workers are loss averse. Such preferences imply that the likelihood of quitting for the day will increase just after the target threshold has been crossed.

A second possible interpretation of the targets is that they are an internal commitment device akin to a "personal rule" (i.e. Ainslie 1992; Bénabou and Tirole 2004). Once set, workers may not want to renege on this commitment because they fear it will create a precedent for future days. Such a rule would also result in an increase in quitting behavior after the target has been reached.

How, then, are the daily targets themselves determined, or what rule do they follow? As discussed in Köszegi and Rabin (2006), under rational expectations, targets will be forecasts of the day's expected earnings. We will further test whether cash needs, expected or unexpected, affect targets. Furthermore, if workers are present-biased in effort, putting off dealing with needs until they can no longer do so, targets will be affected by the current day's needs, but not later ones, because workers then know that they "must" earn the money that day.

Such preferences generate several predictions which we take to the data:

1. Workers will put off dealing with needs until they can no longer do so.

2. Workers will work more on days in which their needs are larger.

3. The hazard of quitting will increase after reaching the day's cash need.

4. As in Camerer et al. (1997), workers will display a negative wage elasticity with respect to hours worked.

\section{Sample and Data}

\subsection{Sampling Frame}

The project took place in the Busia district of Western Kenya in Summer and Fall 2009. The sample was drawn in August, and the logs were collected between September and December. To draw the sample, enumerators conducted a census of all bicycle-taxi drivers (locally known as "bodas") in 14 market places scattered around the district. Individuals were included in the sample only if their primary occupation was as a bicycle taxi driver. 
The only sample restriction was that the respondent had to be able to read and fill out the logs. We therefore excluded individuals who could neither read nor write or who had fewer than three years of schooling (24\% of those in the census), leaving 303 eligible individuals. We were able to successfully enroll 257 (85\%) of these in the study. The remainder could not be enrolled for one of three reasons: they had moved out of the area, had quit boda work, or did not consent to the relatively heavy data collection requirements.

\subsection{Data}

The data collection took place over a 3 month interval, from September to December 2009. Individuals were enrolled on a rolling basis (the last round of individuals were enrolled in late November).$^{5}$ There are two primary data sources we use for the analysis.

\subsubsection{Baseline Survey}

Each individual who was enrolled in the study was administered a baseline survey $\left[6^{6}\right.$ In addition to basic household demographic information, the survey included a number of measures to inform the subgroup analysis. These include a financial module, a health module, and a module to construct measures of time preferences, risk preferences, and loss aversion.7

\subsubsection{Logs}

Building on the successful use of logs in previous studies in the same area of Kenya (see Robinson and Yeh 2011 and Dupas and Robinson 2013a for data from self-filled daily logs collected among sex workers and market vendors / bicycle-taxi drivers, respectively), we asked each study participant to keep a daily labor supply log for up to three months. The logs were pre-printed in a two-page questionnaire form with 7 rows per page (corresponding to 7 days, with pre-printed dates) with blanks for study participants to fill in the relevant information. To incentivize participants to fill the logs well, respondents were given in-kind gifts (e.g. soap, cooking fat, sugar) worth around 75 Kenyan shillings (\$1) for each week in which they filled the log competently: ${ }^{8}$

Respondents were instructed to fill in the log throughout the day, indicating the precise time at which they started working, the timing of each client pickup and dropoff, the fare,

\footnotetext{
${ }^{5}$ The sample was drawn on a rolling basis because the fixed cost of training a respondent to keep the log was large so it took some time to train respondents.

${ }^{6}$ This survey, as well as the daily and weekly logs described below, can be found on the authors' websites.

${ }^{7}$ The baseline was conducted in parallel with the beginning of the data collection process. Baseline data is missing for 12 of the 257 workers in our sample.

${ }^{8}$ The exchange rate was approximately 75 Kenyan shillings (Ksh) to $\$ 1$ US during this time period.
} 
and the time they stopped working 9 Crucially, the logs also included questions on daily needs. The first question on the log was: "Is there something in particular that you need money for today?" and included codes for a variety of common options such as bicycle repairs, medical expenditures, ROSCA contributions, food, and school fees. There was also a code for "nothing special.'10 If the respondent reported a need, the next question asked the respondent to record the amount necessary to meet this need. The logs also included a few questions on health shocks experienced that day by the individual and other family members.

While the daily logs contain rich information on labor supply, needs, and health shocks, it was not possible to include other questions without making the logs too onerous to complete. Thus, to supplement the daily logs and to regularly check data quality, enumerators visited study participants on a weekly basis. During this visit, the enumerator checked that the logs were filled correctly and collected the completed pages. The enumerator then administered a recall survey to the respondent. For each day in the given week, the enumerator asked about a variety of other outcomes, including labor supply in other jobs (e.g., farming, casual work, selling produce, etc.). The weekly survey also includes more details on health shocks (including symptoms), making it possible to cross-validate the health shock information recorded in the daily logs. 11

As mentioned above, bodas were enrolled into the study on a rolling basis. There is therefore variation in how long bodas were asked to keep logs. Of the bodas in the final sample, logs were kept for between 1 week and 3 months. The median boda kept the log for 49 days (the mean is 52 days). We have an accompanying 1 -week recall survey for $72 \%$ of the days ${ }^{12}$ The median boda has full data for 35 days (the mean is 38 days).

\subsection{Experimental Income Shocks}

To introduce random variation in non-labor income across days for a given individual, we invited respondents to participate in a free lottery a few times over the course of the study. These lotteries were not announced in advance. Study participants were randomly selected to be invited to come to their local market center on that same day and pick a prize from a bag. Lottery participants had a 50\% chance to win only $20 \mathrm{Ksh}$ (the small prize), and a

\footnotetext{
${ }^{9}$ Respondents were given watches to record the time.

${ }^{10}$ This code was reported on $8.4 \%$ of days. Results look very similar when these days are removed from analysis.

${ }^{11}$ In the interest of time, expenditures were not recorded.

${ }^{12}$ The reason why the 1 -week recall survey is missing for some days is that enumerators sometimes were not able to find the respondent to collect the daily log (e.g., if the respondent had traveled). In that case, the enumerator would attempt to find the respondent the following week, but then only administered the 1-week recall survey for that week.
} 
$50 \%$ change to win a large prize (namely, a $25 \%$ chance to win $200 \mathrm{Ksh}$, a $12.5 \%$ chance to win $250 \mathrm{Ksh}$, and a $12.5 \%$ to win $300 \mathrm{Ksh}$ ). The odds and prize sizes were not disclosed to participants. Given that average daily income (conditional on working) is approximately $150 \mathrm{Ksh}$, the lottery prizes were substantial. The prizes are also large relative to daily cash needs, which (conditional on having a need) average around 200 Ksh (see Table 2).

Each boda was sampled to participate in at least one and up to four lotteries over the course of two months. ${ }^{13}$ If a participant could not be located on a given lottery day, he was never told about the lottery he missed ${ }^{14}$

\subsection{Sample Characteristics}

Table 1 presents baseline characteristics for our study sample. All study participants are male, since bicycle-taxi driving is an exclusively male occupation. $75 \%$ of respondents participate in Rotating Savings and Credit Associations (ROSCAs). While $32 \%$ have bank accounts, few use them regularly (see Table 2), possibly owing to the fact that banks in this area tend to have substantial withdrawal fees, limited opening hours, and few rural branches.

As a way to estimate levels of current savings, the baseline asked respondents the following open-ended question: "If you absolutely needed 1,000 Ksh, how would you get the money?" (answers were coded after the respondent has answered). While 1,000 Ksh is a substantial sum (equivalent to about a week's worth of income), it is not very large relative to lifetime income and is the type of shock that people do encounter in reality (for example, for a serious medical problem which requires hospitalization). Although respondents could list as many responses as they wanted, only $10 \%$ of people reported being able to use savings for even part of the amount. Most people reported that they would have to rely on friends or family for help (47\%) or would have to resort to selling assets (34\%).

Health status appears relatively poor among bodas in the sample. Even though the average boda is only 32 years old, 39\% missed at least 1 day of work in the month prior to the baseline due to sickness. The baseline also collected information on a number of physical symptoms, coded as 1 for none, 2 for mild, 3 for moderate, 4 for severe, and 5 for extreme. We then aggregate these into a "health problems" index. The average of this is just 1.97, corresponding to mild on average. However, a substantial fraction of people report worse health (see Appendix Table A1).

Reference-dependence requires that individuals be loss averse around a target. Consistent

\footnotetext{
${ }^{13}$ Overall, $2 \%$ of study participants participated in four lotteries, $47 \%$ participated in three lotteries, $38 \%$ participated in two lotteries, $6 \%$ participated in only one lottery, and $7 \%$ did not participate in any lotteries.

${ }^{14}$ Almost all bodas who were invited played the lottery that day - in only $4 \%$ of cases did a boda not show up to play the lottery after being invited.
} 
with this, Fehr and Goette (2007) find that lab experimental measures of loss aversion predict behavior in their experiment among bicycle messengers in Switzerland. Following them, we collected measures both of loss aversion and of small-stakes risk aversion. We measure loss aversion by asking respondents whether they would accept a gamble in which there is a $50 \%$ chance that they would win some amount and a 50\% chance they would lose a smaller amount. Overall, 28\% refuse a 50/50 chance of winning $30 \mathrm{Ksh}$ or losing $10 \mathrm{Ksh}$, while $58 \%$ refuse a 50/50 chance of winning $120 \mathrm{Ksh}$ or losing $50 \mathrm{Ksh}$. To measure small-stakes risk aversion, respondents were asked to divide $100 \mathrm{Ksh}$ between a safe asset in which they kept the amount invested for certain and a risky asset in which the amount invested would be multiplied by 2.5 with $50 \%$ probability and would be lost with $50 \%$ probability. Note that because the stakes are so low, an expected utility maximizer should be close to risk averse over this sort of gamble and so should invest close to the full amount (Rabin 2000). Loss averse respondents, by contrast, may invest less. Indeed, the average respondent in our sample invested just over half ( $56.2 \mathrm{Ksh})$ in the asset, further suggesting that a significant fraction of respondents may be loss averse.

\subsection{Summary Statistics from Logs}

Table 2 presents summary statistics from the logs. From Panel A, respondents work on $74 \%$ of the days in our sample. Conditional on working, average income is around $\$ 2$ per day. Consistent with Table 1, bike taxiing is the primary source of income - respondents received other income on only $24 \%$ of days. Panel B shows that needs are very common: respondents report daily needs on $88 \%$ of days. Conditional on having a need, the average amount needed is quite substantial: at around $200 \mathrm{Ksh}$, it exceeds average income. There is also substantial variation in needs: needs range from a minimum of 5 Ksh to over 1,500 Ksh, and the standard deviation is $340 \mathrm{Ksh}$. Much of this variation is within individual across days: the within-individual standard deviation (296 Ksh) is larger than the inter-individual standard deviation (168 Ksh).

As can be seen from Panel C, shocks are quite common. For example, respondents report that they are sick on $18 \%$ of days and report that another family member is sick on $10 \%$ of days. Respondents also commonly need money for other expenses. Individuals report needing cash to pay school fees on $2 \%$ of days, needing to contribute to a funeral on $5 \%$ of days, and needing to make bicycle repairs on $21 \%$ of days. Finally, Panel E shows two other individual-level variables of interest: $24 \%$ of respondents receive lumpy, irregular payments from regular customers (typically payment for taking a child to and from school) and $17 \%$ of respondents rent their bikes from someone else. 


\section{Results}

\subsection{Determinants of Daily Cash Needs}

In Table 3, we examine how time-varying factors affect needs and labor supply. In particular, we run the following regressions:

$$
N_{i t}=\beta w_{i t}+S_{i t}^{u} \gamma^{u}+S_{i t}^{e} \gamma^{e}+\eta_{i t}+\mu_{i}+\epsilon_{i t}
$$

where $N_{i t}$ is a measure of the daily need, $S_{i t}^{u}$ represent unexpected shocks (such as sickness or funeral expenses), and $S_{i t}^{e}$ represent expected events which require cash (such as ROSCA payments or school fees coming due). We also include a measure of the realized wage rate $\left(w_{i t}\right)$. Since an individual's wage is, of course, endogenous, we follow Camerer et al. (1997) and construct a realized wage that is exogenous to the individual by taking the average wage of all of the other bodas in that market center. Finally, we include fixed effects for the day of the week and the week of the year $\left(\eta_{i t}\right)$ in the specification, since these are predictable determinants of the wage. The regressions include individual fixed effects, and errors are clustered at the individual level.

We consider three measures of the daily need. First, we examine need amounts across all days by imputing a need value of 0 for days in which no need is reported (column 1). Second, we consider a dummy for whether a cash need is reported that day (the extensive margin, column 2). Third, we consider the amount needed, conditional on reporting a need (the intensive margin, column 3).

We find that several of the shock measures (whether expected or unexpected) are correlated with needs. Funerals and the illness of another household member are robustly correlated with all the need measures. School fees and ROSCA contributions are also correlated with reporting a need.

In contrast, needs are not strongly correlated with the local wage rate (if anything, the correlation is negative). This result, coupled with the result that the needs are highly correlated with the exogenous shocks, helps to rule out the concern that workers may endogenously "choose" to consider a need (e.g., choose to pay pending school fees) on days when they know they can earn more. Needs are also largely uncorrelated with the day of the week, with one exception: people are less likely to report needs on Sundays and are more likely to report them on Monday. There are two potential explanations for this. First, people may actually have less needs on Sundays (for example, school fees and other bills are unlikely to be due on a Sunday). Second, people may choose to "put off" some needs on Sunday. We lack the ability to parse these out. In any case, the evidence on the whole suggests that the needs 
are largely exogenous to labor market conditions.

In Table A2, we cross-check the needs reported on the daily logs with the actual expenditures for that day as reported in the weekly recall survey. Specifically, we regress whether a specific type of need was recorded on the daily log (e.g. for ROSCAs, school fees, funeral expenses, bike repairs, and loan repayment) on whether the respondent reported expenditures of that same type on that same day, as per the weekly survey. There are several comforting results. First, reported needs and actual expenditures are strongly correlated for all types of spending, providing some assurance of data quality. Second, since ROSCA payments and school fees are due on specific days outside of individuals' control, this helps to rule out endogenous reporting of needs (an issue to which we return to in section 5.2.2.

Another important result comes from the even-numbered columns, which include controls for whether the respondent will have that expenditure in the next few days. For example, Column 2 shows whether the respondent reports needing money for a ROSCA in the 2 days before the ROSCA payment is actually due. Interestingly, the coefficients are negative and significant, suggesting that people delay considering these pending expenses as things they need to raise cash for until the last possible moment. The other categories show no evidence of anticipating needs in advance. While this is not surprising for unexpected shocks like a funeral or bike repairs, it is more surprising for school fees, and potentially for loan repayment as well (since these events are anticipated). These results suggest that people procrastinate on their needs until they actually need the cash.

\subsection{Cash Needs and Daily Labor Supply}

\subsubsection{Cross-sectional evidence}

We start by showing simple correlations between the cash need and labor supply intensity (at the day level). We pool all individuals together for this exercise, so that comparisons are both across days and across individuals. Results are shown in Figure 1 for average hours (top panel) and average income earned (bottom panel). We limit the sample to cash need amounts with at least 50 observations (that is, 50 individual-days), and observations are weighted by the frequency of that need amount (represented by the size of the circle). The figure shows a very clear positive relationship between the cash need for the day and the labor supply that day.

\subsubsection{Within-Driver Variation Across Days}

The simple correlations in Figure 1 could of course reflect differences across individuals, rather than within-individual variation across days. We turn next to regression analysis 
with individual fixed effects, and exploit within-driver variation in cash needs across days. In particular, in Table 4 we estimate the following

$$
L_{i t}=\beta w_{i t}+\gamma N_{i t}+X_{i t} \delta+\eta_{i t}+\mu_{i}+\epsilon_{i t}
$$

where the dependent variable is a measure of daily labor supply for individual $i$ at date $t$, and as above, $N_{i t}$ is a measure of the need for that individual on that date. We present specifications with two measures of the need: the odd numbered columns include a dummy for having a need, while the even numbered columns include the log of the cash need for those that have one. The vector of control regressors $X_{i t}$ include the measure of the realized wage rate that day as described above, and (though the coefficients are not reported) the day of the week and the week of the year, whether it rained, and whether the driver was sick that day ${ }_{15}$ As before, the standard errors are clustered at the individual level.

On the whole, the results are consistent with Figure 1. On days in which they have needs, individuals are more likely to work (and therefore earn more money). And conditional on having a need, individuals with a higher need have more passengers, work longer hours, and spend more of the work day carrying passengers. ${ }^{16}$ The effect sizes are substantial: individuals are 18.9 percentage points more likely to work when they have a need and, conditional on having a need, a $100 \%$ increase in the need amount translates into approximately a $10 \%$ increase in earned income.

Another interesting result is that as in Camerer et al. (2007) and subsequent papers, we observe what appears to be a negative wage-elasticity - bicycle-taxi drivers appear to work fewer hours on higher-wage days. On the other hand, on the extensive margin, people are more likely to work when the wage is higher, as in for example Oettinger (1999).

\subsubsection{Within-Driver, Within-Day Hazard Analysis}

In this section, we estimate the hazard of quitting around the daily need amount. Note that under income targeting, since the cash need is potentially only one component of the (unmeasured) target, the estimated effect of reaching the target will be downwardly biased.

\footnotetext{
${ }^{15}$ As some of the variation in wages is across days of the week (for example, wages are higher on market days when people buy and sell items in the town), this regression could be run without day of the week controls. However, the overall pattern of results is similar with or without day controls (in part because market days vary across locations).

${ }^{16}$ Potentially there could be adjustment on the fare as well (i.e. the driver gives a discount) - see Keniston 2011 for evidence of significant bargaining between rickshaw drivers and passengers in India. This is unlikely for short rides (since the norm is of a minimum fare of 10 or 20 Kenyan shilling), but could be relevant for longer rides. While it is difficult for us to check this (since we do not know how long a particular ride is, in distance), we can provide some evidence by looking at the average fare per minute of a given ride. We do not observe any relationship between this measure and needs.
} 
We estimate the hazard with the following non-parametric regression

$$
q_{i p t}=\sum_{b=-10}^{10} \gamma_{b} D_{i b t}+\delta H_{i p t}+\psi H_{i p t}^{2}+\eta N_{i t}+\mu_{i}+\eta_{t}+\epsilon_{i p t}
$$

where $q_{i p t}$ is a dummy for quitting after passenger $p$ on date $t, H_{i p t}$ is hours worked up to that passenger, and $N_{i t}$ is the need amount for that date. ${ }^{17}$ The key parameters of interest are the $\gamma_{b}$ coefficients, which are dummies for being in income bin $b$, relative to the need amount (these bins are of width $20 \mathrm{Ksh}$ ) 18

If people are reference-dependent or if the marginal utility gain drops as soon as the daily need is taken care of, we would expect the coefficients $\gamma_{b}$ to be larger after the threshold has been reached (i.e. for $b \geq 0$ ), compared to those before the threshold (i.e. for $b<0$ ).

We plot these coefficients, and associated 95\% confidence intervals, in Figure 2. As can be seen, there is a dramatic increase in the probability of quitting at the need amount.19 The probability of quitting continues to rise after that point, as well (note that this graph is the conditional probability of quitting, so that the cumulative probability is larger). ${ }^{20}$

Lastly, we run a parametric regression to formally test whether reaching the target affects quitting behavior:

$$
q_{i p t}=\alpha+\gamma_{1} O_{i p t}+\beta_{1} D_{i p t}+\theta_{1} D_{i p t} * O_{i p t}+\delta H_{i p t}+\psi H_{i p t}^{2}+\eta N_{i t}+\mu_{i}+\eta_{t}+\epsilon_{i p t}
$$

where $D_{i p t}$ is the difference between the daily need and income earned until passenger $p$ and $O_{i p t}$ is a dummy equal to 1 if total income has exceeded the daily need. From the figures, we anticipate that both $\gamma_{1}$ and $\theta_{1}$ should be positive. This analysis is presented in

\footnotetext{
${ }^{17}$ Results look identical when controlling for hours spent riding rather than total hours spent working (which includes waiting time).

${ }^{18}$ The overall pattern looks similar with other bin sizes (results available on request). Using a smaller bin is problematic in that very few fares are less than $20 \mathrm{Ksh}$, while using a larger bin attenuates effects.

${ }^{19}$ Note that while the graph appears to show a flat hazard below the threshold, the hazard is conditional on total hours worked (and the square of total hours). Without a control for hours worked, there is a small increase in the hazard below the threshold. We present the results with the hours controls because inference is crisper when controlling for a smooth function of hours.

${ }^{20} \mathrm{~A}$ potential complication in estimating the hazard is that need amounts vary across day so there is a (mechanical) potential sample composition issue in comparing coefficients (for example, observations in bins far over the threshold mostly involve days in which the need amount is very low). Note, however, that this issue is much less severe right around the threshold than at points further away (since on average sample composition shouldn't change discontinuously at that point). To further confirm that this sample composition is not affecting our results, we perform two sets of tests. First, we run regressions restricting the need size to a fairly narrow range. This, of course, greatly reduces power but yields a qualitatively similar overall pattern (see the bottom panel of Figure 2). Second, we run specifications with fixed effects at the individual-day level. These regressions, which by definition control for the need amount, yield a similar pattern. However, since they greatly restrict variation and consequently reduce power, we do not include them in the main tables.
} 
column 1 of Table 4. The coefficient on the dummy for exceeding the target is positive and significant at the $1 \%$ level.

\subsection{Unexpected Cash Windfalls and Labor Supply}

As discussed previously, we invited bodas to participate in a free (unannounced) lottery a few times over the course of the study. Individuals were invited to come to their local market center on that same day and pick a prize from a bag. Lottery participants had a $50 \%$ chance to win only $20 \mathrm{Ksh}$ (the small prize), and a $50 \%$ chance to win a large prize (namely, a $25 \%$ chance to win $200 \mathrm{Ksh}$, a $12.5 \%$ chance to win $250 \mathrm{Ksh}$, and a $12.5 \%$ to win $300 \mathrm{Ksh}$ ). These are substantial sums relative to average daily income from bike taxiing of $145 \mathrm{Ksh}$ (conditional on working) 21

To examine the effect of these unexpected cash windfalls, we regress total hours on whether the respondent won one of the large amounts (an amount greater than $200 \mathrm{Ksh}$ ) in Table 6 (the regressions include boda fixed effects). ${ }^{22}$ Interestingly, we find no effect of the lottery on any measure of labor supply.23 A hazard analysis (not shown) finds no evidence whatsoever of a change in the quitting hazard right after the payment. Thus, the labor supply response to the shocks is consistent with a standard lifetime neoclassical labor supply model.

How can this be reconciled with our previous results which provide strong evidence for reference dependence? We conjecture that the explanation is that daily income targets are labor (earned) income targets that are set early in the day (most likely before they start work) - not total income targets. Once workers have set these targets in the morning, they follow through on their plan whether or not they receive unexpected income shocks. In the next section, we conjecture that workers may be using such labor income targets as a self-control device, i.e. a way to motivate themselves to work despite the unpleasant nature of their job.

\footnotetext{
${ }^{21}$ The timing of payouts in the day was random - some people were selected to receive payments in the morning and others in the afternoon, though typically the payments were made after respondents had started work for the day. We do not observe any heterogeneity in behavior based on the timing of the payment.

${ }^{22}$ The regressions include all days, including those in which no lottery was played. This is because the disruption of the lottery was minimal, taking only a few minutes, and because results look very similar even when restricting to lottery days alone (results on request).

${ }^{23}$ We also find no effect of the lottery payment and needs in subsequent days.
} 


\subsection{Discussion}

\subsubsection{Mental targets as commitment devices}

As discussed in Camerer et al. (1997), mental income targets could be a way for daily income earners to solve self-control problems: present-biased workers who can set their own hours may be tempted to quit too early, and setting a target before starting work in the morning may be a way to avoid succumbing to that temptation. This explanation is plausible for workers in our sample: bike-taxiing in the hot sun is strenuous and unpleasant, and given the relatively poor health of drivers in our sample, possibly painful as well. ${ }^{24}$

But how can a mental target be strong enough to work as a commitment device? If all one needs to motivate oneself is to set a target, then everyone should pick an optimal target which maximizes intertemporal utility (i.e. behave exactly as in a neoclassical labor supply model).

Clearly that is asking too much from mental targets, and that is not what we observe in the data, whether in our Kenya sample or in other parts of the world. Instead, it seems that people need some external device to help make the target binding. For example, recent work by Kaur et al. (2010, 2013) shows that data entry clerks in India willingly accept wage contracts which penalize them, in terms of pay, if they fail to reach a self-chosen target, suggesting demand for an external commitment to help them overcome present-bias. Among US undergraduates, Augenblick et al. (2013) find a strong demand for commitment devices to not put off tedious effort tasks.

Absent such external devices, our data suggests that workers use a heuristic to set a binding mental target: the amount they need to meet their cash needs that day. On days affected by particularly bad income shocks, workers are motivated to work harder than usual. Even if they receive a positive windfall in the middle of the day (such as an experimental lottery payment), they keep working hard since they had mentally prepared themselves to work hard that day. That the target cannot be undone by an unexpected income shock is important: if it were, then mental income targeting would be a very weak internal commitment device to provide effort. ${ }^{25}$ The flip side of the simple heuristic used to set the target is that people quit earlier on days in which they do not have a pressing need.

\footnotetext{
${ }^{24}$ Those in worse health at baseline appear no more likely to respond to reaching the target, but individuals in worse health are more likely to quit at all income levels, and work less overall.

${ }^{25}$ We also find no effect of a "real world" cash payout - receiving the cash pot - on labor supply. Note however that the ROSCA payout is expected in advance.
} 


\subsubsection{Targets and Expected Earnings}

If the effect of the need on labor supply indeed takes effect through a mental income targeting mechanism, then as discussed in Köszegi and Rabin (2006) and Crawford and Meng (2011), the income target would likely be determined by expectations over earnings, and not only the exogenous need. To examine both together, we integrate our results with those of Crawford and Meng (2011). In that study, the authors use average daily income or hours (by driver and day of the week) in previous days as a proxy for the target. We replicate that analysis in Table 7. The odd numbered columns replicate Crawford and Meng, while the even numbered columns include a dummy for being over the need amount. As can be seen, we replicate the finding that reaching either the income or hours target increases the likelihood of quitting in all specifications. When we add in our need measure, we find that all three coefficients are significant, suggesting that both earning expectations and the daily need matter and affect the target. If income expectations matter, then why do we observe such a stark discontinuity at the need? Table A3 appears to offer an explanation: earning expectations based on previous earning history are uncorrelated with the need amounts.

One final point of comparison can be seen when we graph the Crawford and Meng results in Appendix Figure A1. As would be expected if wage rates or targets vary across days, the discontinuity at the target proxy is less sharp using this approach (especially for hours). This underscores the value of having an explicit measure of the daily need in our dataset.

\section{Heterogeneity, Robustness, and Alternative Expla- nations}

\section{$5.1 \quad$ Heterogeneity}

One important question is whether certain workers are better able to take advantage of neoclassical intertemporal substitution. One such group might be more educated workers, for example because recent evidence suggests that cognitive ability is correlated with preferences over risk and time. ${ }^{26}$ Indeed, a Mincer equation yields a coefficient on years of education of 3.7-4\% in our sample (Appendix Table A4, columns 1 and 2), even conditional on a host of covariates. A decomposition of this effect in the other columns of Table A4 and Figure A2 shows that more educated workers do not work longer or take on more passengers, nor do

\footnotetext{
${ }^{26}$ See, for example, Frederick (2005); Dohmen, Falk, Huffman, and Sunde (2010); Burks, Carpenter, Goette, and Rustichini (2009); and Benjamin, Brown, and Shapiro (2013). Similarly, Kremer et al. (2013a) show that small-stakes risk aversion is correlated with inventory and profit levels among Kenyan retail shops.
} 
they better optimize on the extensive margin, but their effective wage rate is higher. Is it possible that such workers are less prone to income targeting?

We examine this in Panel A of Figure 3, in which we examine quitting behavior for more and less educated workers. Education varies from 0 to 12 years, and is bunched around 7 (the 25 th percentile is 6 , the median is 7 , and the 75 th percentile is 8$)$. For this analysis, we split the sample at 6 years of education (the 25 th percentile of the education distribution). From the figure, it indeed does appear that more educated workers are less sensitive to reaching the daily need (even though the patterns of daily needs does not systematically vary by education level). In contrast to other papers, we find little correlation between education and measures of preferences, however (educated workers are slightly more patient, but do not differ in terms of loss aversion, small-stakes risk aversion, of time consistency - results available upon request). What's more, we do not observe significant heterogeneity in quitting at the daily need amount by our measure of loss aversion (Panel B of Figure 3).27

The right-hand columns in Table 4 formally tests for heterogeneity. Each row repeats the parametric regression above, but also includes interactions with the background characteristic of interest. We focus on several measures of education (being in the top $75 \%$ of the education distribution, being in the top $50 \%$, and years of education), as well as a measure of loss aversion (refusing a 50/50 gamble to win $30 \mathrm{Ksh}$ or lose $10 \mathrm{Ksh}$ ). The interaction between these variables and the dummy for reaching the target is significant for 2 of our 3 education measures, but not for our measure of loss aversion.

Overall, our findings suggest that more educated workers are better able to adjust behavior at the margin, i.e. stay on for an extra passenger or two after reaching their daily need. Table 8 shows the effect of this in a regression framework. In this table, we regress labor supply on an indicator for having a "big day" (i.e. the local wage is higher than the median), and an interaction between this and being in the top $75 \%$ of the education distribution. Though many coefficients are of borderline significance, more educated workers make more money on such days and have a higher own wage rate, suggesting that when the stakes are high they are better able to continue working past the daily need threshold. A back of the envelope calculation suggests that $37 \%$ of the education wage premium is on income earned above the daily need. While speculative, these results suggest a potential role for education, even in a setting which otherwise would seem to require little human capital.

\footnotetext{
${ }^{27}$ One possible reason we do not find a correlation whereas Fehr and Goette (2007) do is that the stakes in our gambles were relatively larger (around $2 / 3$ daily income, compared to less than $5 \%$ in Fehr and Goette 2007). They are still an insignificant fraction of lifetime income, however.
} 


\subsection{Robustness}

This section discusses two potential threats to the analysis above. First, there may exist experimenter effects, given the high frequency and nature of the data collected. Second, it might be possible that the timing of cash needs is endogenous.

\subsubsection{Experimenter effects}

The log asked individuals to record their cash need at the beginning of every day. One may worry that simply asking this question made that specific amount salient in respondents' minds, especially those with a lower level of education. It is also possible that respondents felt an experimenter demand effect, i.e. that respondents believed that the researchers expected them to work up to the need, and then quit thereafter. In this section we argue that these two types of experimenter effects are unlikely to be driving our results.

The most convincing test of the presence of such experimenter effects would be if we had a comparable group of bicycle taxi drivers who were asked to fill logs similar to those we used, except for the question on the daily cash need. We could then check whether workers who were asked to state their cash need exhibit more variance in hours than workers who were not. Though we cannot test this directly since all of the workers in our study were asked about the need, we can compare the variance in hours we observe in our sample to that of bicycle taxi drivers followed in Dupas and Robinson (2013a). While that data was collected between 2006 and 2008 (i.e. 1 to 3 years earlier than the present study), it was collected using almost identical logbooks except that they did not include the question on the day's needs. Interestingly, we find comparable (and if anything, larger) within-worker variance in hours worked across days in that earlier sample: 2.74 compared to 2.16 in the sample considered in the present paper. This at least suggests that the large within-individual variance in daily labor supply is not an artefact of our data collection protocol.

A second way to test whether the data collection made needs particularly salient and therefore accentuated income-targeting is to check how persistent the effects are. If people were not income targeting at all before the study, but then began to do so after keeping the logs since the cash needs became salient, then such respondents should eventually have switched back to their previous behavior after some time, since income targeting reduces total income on average. Thus, if this were the explanation, then one would expect the evidence of targeting to fade over time. When we run the hazard analysis separately for the first and last month during which individuals were keeping the logs, however, we find the exact same pattern of results, with the same magnitude, for both time periods. This further suggests that experimenter effects are unlikely explanations for our results. 


\subsubsection{Endogenous timing of needs}

While many of the determinants of the cash needs reported by our study participants are

almost certainly exogenous and unexpected (e.g. health shocks, funerals), some can be anticipated (e.g. food for the household). For such anticipated needs, workers may choose the days in which they decide to "deal" with those - for example, they may decide to purchase food on the day they expect to make more money, or they may decide to pay school fees on the day they wake up feeling in particularly good health. If that is the case, workers would mechanically report higher needs on days in which they expect to make more money, explaining the positive correlation we observe between needs and labor supply. While this may be the case on the extensive margin - on Sundays, which is much less likely to be a work day than other days, respondents typically report smaller cash needs - this does not appear to be the case on the intensive margin, which is the focus of our paper. Indeed, as was mentioned earlier and shown in column 2 of Table 3, reported needs in our data are not positively correlated with the wage rate. What's more, as shown in Table A2, people report needs such as savings club payments exactly on the days in which these are paid (and these savings club payments are on fixed schedule that workers cannot unilaterally decide on). Finally, if we restrict the sample to individual-days with only unexpected needs, we see the exact same pattern of results. Overall, endogeneity of the timing of daily needs seem an unlikely explanation for our results.

\subsection{Ruling out alternative explanations}

\subsubsection{Subsistence Constraints}

Our preferred explanation for these results is that workers in our sample have income targets which serve either as reference points or personal rules. One could however think of alternative explanations, notably that observed behavior can be explained by a model of labor supply under subsistence constraints (for a recent example, see Halliday 2012). In our context, the daily need may represent the subsistence constraint, after which workers quit for various reasons. A first alternative could be that workers switch to an activity with higher returns but delayed payoffs after reaching the subsistence constraint, such as cash crop farming. This is unlikely to be the sole explanation for our results, however, since only $15 \%$ of respondents have another source of regular income and only $20 \%$ have seasonal income (Table 1). In any case, as can be seen in Figure A3, which show the results of heterogeneity analyses identical to those performed in Figure 3 and Table 7, we do not observe statistically significant differences between people who have other sources of income and people who don't. 
A second alternative could be that people are almost completely unable to save, such that any money beyond the immediate cash need is close to valueless. While people in the study area lack access to reliable cash savings instruments and have been shown to have trouble saving money (Dupas et al., 2012; Dupas and Robinson, 2013b), it is hard to imagine that savings difficulties could be so extreme as to prevent people from transferring resources across a single day - in Dupas and Robinson (2013b) we find that people in the study area are able to accumulate money over at least a few days before depositing money into bank accounts.

A third possibility is that effort costs are so high that it is optimal to stop work immediately after reaching the need. Note, however, that this is unlikely to be an explanation unless it interacts with savings problems or present-bias in effort, since over the course of even a few days a worker will end up working more by quitting at the need than if he worked similar hours every day. A final possibility is that people have a limited attention constraint and so don't pay attention to their needs until the day that they are due. This, however, seems somewhat unlikely in that people do report wanting to save for non-immediate goals.

While all these alternative explanations appear unlikely to start with, we can reject them formally by using the experimental variation in unearned income from the lotteries. Each of these alternative theories predict that as soon as the subsistence need is taken care of, workers should quit bike taxiing for the day - but that prediction is strongly rejected by our experimental finding that workers' labor supply is unaffected by large lottery wins.

\subsubsection{Risk Sharing}

Another potential explanation is related to the fact that the bicycle taxi drivers in our sample work in a specified area (or "stage"). In that context, it's possible that workers have developed a risk-sharing institution in which customers are funneled towards those workers who most need the money. If a particular worker has a need, he is more likely to get a customer until he reaches that need, after which competition goes back to normal. While such a situation would produce a pattern of results similar to what we find here, we view is at unlikely for several reasons. First, this type of cooperation seems to be fairly rare in these sorts of labor markets. For example, Kremer et al. (2013b) find that shops often fail to buy enough to qualify for bulk discounts, yet shopkeepers almost never report splitting orders with another shop. Second, needs are so common that there would be relatively few days in which people could insure each other (from Table 2, respondents report needs on $88 \%$ of days and the average need amount exceeds total daily income). Third, to the extent that working very long hours on some days reduces health capital (see Section 6 for some evidence that it does), such a scheme is dominated by simply providing cash payments to each other. 
Fourth, such a scheme is only sustainable if both income and needs are observable to other people, yet the specific value of various needs seems hard to value, and it might be hard to monitor income given that some fares are taken away from the stage (for example, a return trip from town).

Nevertheless, we can check this more formally by constructing measures of the proportion of other workers in that stage with a need on that day, and the average need amount (this is the same approach used to construct the realized market wage rate), and then checking whether the total income of a worker on particular day is lower when more of the other workers in the area have needs. We find no evidence for this - the coefficients on either the share of workers with a need or the total need value of other workers are insignificant in nearly all specifications, suggesting that the form of risk sharing we describe above is not the explanation.

\section{Dynamic Impacts and Welfare Implications}

The overall pattern of our results suggests that income targets serve as a sort of internal commitment device to meet daily cash needs. What are the ultimate welfare consequences of setting labor supply in this way, relative to fully optimizing intertemporally? In this section, we present some speculative evidence on this issue, focusing both on income and on health.

The basic implication of income targeting is that a worker will, for a given effort target, work less on days in which the wage is higher. Consequently, a worker will work more hours for the same level of income than he would have if he substituted intertemporally. How much income are workers in our sample giving up?

It is difficult to quantify this empirically, since a perfectly optimizing worker would want to work more on days in which the wage is high but it is difficult for us to predict wage fluctuations with the data we have. We therefore estimate lost income in two ways: (1) a lower bound in which the worker supplies equal hours every day; (2) and an estimate based on a labor supply elasticity of 0.15 (the mean micro labor supply elasticity reported by Chetty 2012) ${ }^{28}$ We present a CDF of the percentage increase in income that adopting such rules would yield in Figure 4.

The fixed hour rules yields mean and median increase in income of $5.0 \%$ and $2.5 \%$, while the estimate based on a 0.15 elasticity gives mean and median estimates of $8.0 \%$ and $5.0 \% .29$ This estimate of lost income is of comparable magnitude to Camerer et al. (1997), who

\footnotetext{
${ }^{28}$ Note that this calculation is equivalent to calculating the percentage reduction in hours that a worker could realize while earning the same income.

${ }^{29}$ Lost income is large for at least a minority of workers. It is also interesting that only about $10 \%$ of people in our sample would reduce income if they worked a fixed number of hours per day.
} 
estimate approximately a 5\% increase in wages from a fixed hours rule, and Kaur et al. (2013) who estimate a treatment on the treated productivity effect of $6 \%$ to giving external commitment devices to data workers.

Thus the heuristic adopted by workers (especially those with lower education levels) is not costless. For very poor households such as those in our sample, $5 \%$ of yearly income is more than what it takes to invest in life-saving products that many struggle to find money for, such as antimalarial bednets or water filters. Another benchmark might be the increase in profits due to a random injection of capital among small businesses. For example, de Mel et al. (2008) give random cash grants to Sri Lankan businesses and estimate returns to capital of 4.6-5.3\% per month. Given baseline profits and inventories in their sample, and assuming the grant is not reinvested, increasing profits by $5 \%$ would require a $14-16 \%$ increase in the capital stock 30

There may also be health costs of failing to smooth hours. If strenuous effort has convex health costs, such that health capital gets depleted by working long hours, expending great effort on days in which needs are high may have deleterious effects on long-term health. To provide some evidence on this, we can look at health towards the end of our study period and test whether workers who work more very-long-hours-days are in worse health towards the end of the study period (even conditional on total hours). In Table 9, we perform a descriptive cross-sectional regression, in which we regress endline health on the (log of) total hours worked and the (log of) the standard deviation of hours worked across days. There is thus one observation per worker. The results in Columns 1 and 3 show that workers with higher variance in hours worked across days over the study period are in worse health at the end of the period, though interestingly total hours is not predictive. Since people in poor health may be the ones to experience the most shocks (particularly health shocks), we control for baseline health measures as well, in Columns 2 and 4. The results hold even with these controls. While these regressions are all cross-sectional and ultimately descriptive, they are suggestive.

\section{Conclusion}

We have presented evidence that bicycle-taxi drivers in rural Kenya tend to behave as target earners, quitting soon after making enough money to meet their daily cash need. At the same time, when they receive unexpected and large cash payouts, they do not adjust labor supply. To explain these patterns, we conjecture that, likely owing to the strenuous and

\footnotetext{
${ }^{30}$ Baseline profits in their sample are 3,841 Sri Lankan rupees (LKR) while baseline inventories are 26,530 LKR. Thus, increasing profits by $5 \%$ would require an increase in capital of 3,600-4,200 LKR.
} 
tedious nature of their job, bike-taxi drivers procrastinate on earning enough to cope with cash needs until they can no longer put them off. To overcome the temptation to put off work forever, they treat earning enough for the immediate need as a kind of personal rule - an internal commitment device. Their success in following this rule may come from the fact that they are loss averse over an income target, or that the costs of deviating from the rule are too large, because it would create a precedent for future days. While such a rule is useful for motivating workers, it comes at the cost of reduced income and frailer health for a given number of hours worked.

That people work harder on days when they need money for an expected expense like a ROSCA payment or a school fees bill suggests that workers may be able to smooth labor supply by taking on outlay commitments, for example by taking out loans with high-frequency repayment schedules or joining ROSCAs that meet daily.

An alternative way of increasing productivity could be the introduction of more formal employer-employee work arrangements (as discussed in Kaur et al. 2010, 2013). The finding that a movement to wage work could be beneficial relates to recent work suggesting that many self-employed individuals in poor countries are much more similar (in terms of preferences, attitudes, cognitive ability, motivation, etc.) to wage workers than to large firm owners (i.e. de Mel et al. 2010).

Finally, we find evidence that having more years of education reduces the tendency for income targeting and therefore improves intertemporal arbitrage, another pathway through which education may matter for productivity. 


\section{References}

[1] Abeler, Johannes, Armin Falk, Lorenz Götte and David Huffman (2011). "Reference Points and Effort Provision." American Economic Review 101 (2): 470-492.

[2] Ainslie, George (1992). Picoeconomics: The Interaction of Successive Motivational States within the Individual. Cambridge: Cambridge University Press.

[3] Augenblick, Ned, Muriel Niederle and Charlie Sprenger (2013). "Working Over Time: Dynamic Inconsistency in Real Effort Tasks". Unpublished manuscript, Haas School of Business.

[4] Bénabou, Roland and Jean Tirole (2004). "Willpower and Personal Rules." Journal of Political Economy 112 (4): 848-886.

[5] Benjamin, Daniel J., Sebastian A. Brown, and Jesse M. Shapiro (2013). "Who is Behavioral? Cognitive Ability and Anomalous Preferences." Journal of the European Economic Association. Forthcoming.

[6] Bernartzi, Shlomo and Richard H. Thaler. "Heuristics and Biases in Retirement Savings Behavior." Journal of Economic Perspectives 21(3), (2007): 81-104.

[7] Burks, Stephen V., Jeffrey P. Carpenter, Lorenz Goette, and Aldo Rustichini (2009). "Cognitive skills affect economic preferences, strategic behavior, and job attachment." Proceedings of the National Academy of Sciences 106 (19): 7745-7750.

[8] Camerer, Colin, Linda Babcock, George Loewenstein, and Richard Thaler (1997). "Labor Supply of New York City Cabdrivers: One Day At A Time." Quarterly Journal of Economics 112 (2): 407-41.

[9] Chetty, Raj (2012). "Bounds on Elasticities with Optimization Frictions: A Synthesis of Micro and Macro Evidence on Labor Supply." Econometrica 80 (3): 969-1018.

[10] Crawford, Vincent and Juanjuan Meng (2011). "New York City Cab Drivers' Labor Supply Revisited: Reference-Dependent Preferences with Rational-Expectations Targets for Hours and Income." American Economic Review 101 (5): 1912-1932.

[11] Chang, Tom and Tal Gross (2012). "How Many Pears Would a Pear Packer Pack if a Pear Packer Could Pack Pears at Quasi-Exogenously Varying Piece Rates?" Mimeo, Columbia University.Chou, Yuan K (2002). "Testing Alternative Models of Labour Supply: Evidence from Taxi Drivers in Singapore." Singapore Economic Review 47 (1): $17-47$.

[12] de Mel, Suresh, Christopher Woodruff and David McKenzie (2008). "Returns to Capital in Microenterprises: Evidence from a Field Experiment." Quarterly Journal of 
Economics 123(4): 1329-1372.

[13] de Mel, Suresh, Christopher Woodruff and David McKenzie (2010). "Who are the Microenterprise Owners?: Evidence from Sri Lanka on Tokman v. de Soto. In International Differences in Entrepreneurship, J. Lerner and A. Schoar (eds.), pp. 63-87.

[14] Dohmen, Thomas, Armin Falk, David Huffman and Uwe Sunde. (2010). "Are risk aversion and impatience related to cognitive ability?" American Economic Review 100 (3): $1238-1260$.

[15] Doran, Kirk (2012). "Are Long-term Wage Elasticities of Labor Supply More Negative than Short-term Ones?" Mimeo, University of Notre Dame.

[16] Dupas, Pascaline and Jonathan Robinson (2012). "The (Hidden) Costs of Political Instability: Evidence from Kenya's 2007 Election Crisis". Journal of Development Economics 99 (2): 314-329.

[17] Dupas, Pascaline and Jonathan Robinson (2013a). "Savings Constraints and Microenterprise Development: Evidence from a Field Experiment in Kenya." American Economic Journal: Applied Economics 5 (1): 163-92.

[18] Dupas, Pascaline and Jonathan Robinson (2013b). "Why Don't the Poor Save More? Evidence from Health Savings Experiments." American Economic Review 103 (4): 1138-1171.

[19] Dupas, Pascaline, Sarah Green, Anthony Keats and Jonathan Robinson (2012). "Challenges in Banking the Rural Poor: Evidence from Kenya's Western Province". Forthcoming, NBER Africa Project Conference Volume.

[20] Farber, Henry (2005). "Is Tomorrow Another Day? The Labor Supply of New York City Cabdrivers." Journal of Political Economy 113 (1): 46-82.

[21] Farber, Henry (2008). "Reference-Dependent Preferences and Labor Supply: The Case of New York City Taxi Drivers." American Economic Review 98 (3): 1069-82.

[22] Fehr, Ernst and Lorenz Goette (2007). "Do Workers Work More if Wages Are High? Evidence from a Randomized Field Experiment." American Economic Review 97 (1): 298-317.

[23] Frederick, Shane (2005). "On the ball: Cognitive reflection and decision-making." Journal of Economic Perspectives 19 (4):25-42.

[24] Giné, Xavier, Monica Martinez Bravo, and Marian Vidal-Fernandez (2009). "Intertemporal substitution, weekly target earnings or both? Evidence from daily labor supply of Southern Indian Fishermen," Mimeo, World Bank. 
[25] Goldberg, Jessica (2012). "Kwacha Gonna Do? Experimental Evidence about Labor Supply in Rural Malawi." Mimeo, University of Maryland.

[26] Halliday, Timothy (2012). "Intra-Household Labor Supply, Migration, and Subsistence Constraints in a Risky Environment: Evidence from El Salvador." European Economic Review 56 (6): 1001-1019.

[27] Hossin, Tanjim and John A. List (2012). "The Behavioralist Visits the Factory: Increasing Productivity Using Simple Framing Manipulations." Management Science 58 (12): 2151-2167.

[28] Kaur, Supreet, Michael Kremer and Sendhil Mullainathan (2010). "Self-Control and the Development of Work Arrangements." American Economic Review 100(2): pp. 624-628.

[29] Kaur, Supreet, Michael Kremer and Sendhil Mullainathan (2013). "Self-Control at Work". Unpublished manuscript, Columbia University.

[30] Keniston, Daniel (2011). "Bargaining and Welfare: A Dynamic Structural Analysis of the Autorickshaw Market." Unpublished manuscript, Yale University.

[31] Kremer, Michael, Jean Lee, Jonathan Robinson and Olga Rostapshova (2013b). "The Return to Capital for Small Retailers in Kenya: Evidence from Inventories." Unpublished.

[32] Köszegi, Botond and Matthew Rabin (2006). "A Model of Reference-Dependent Preference." Quarterly Journal of Economics 121 (4): 1133-1165.

[33] Oettinger, Gerald (1999) "An Empirical Analysis of the Daily Labor Supply of Stadium Vendors." Journal of Political Economy 107 (2): 360-92.

[34] Rabin, Matthew (2000) "Risk Aversion and Expected-Utility Theory: A Calibration Theorem." Econometrica 68 (5): 1281-1292.

[35] Robinson, Jonathan and Ethan Yeh (2011). "Transactional Sex as a Response to Risk in Western Kenya." American Economic Journal: Applied Economics 3 (1): 35-64.

[36] Thaler, Richard H., Sunstein, Cass R, (2008). Nudge: Improving Decisions on Health, Wealth, and Happiness. New Haven, CT: Yale University Press. 
Figure 1. Cross-sectional Correlation beetween Cash Need for the Day and Labor Supply that Day

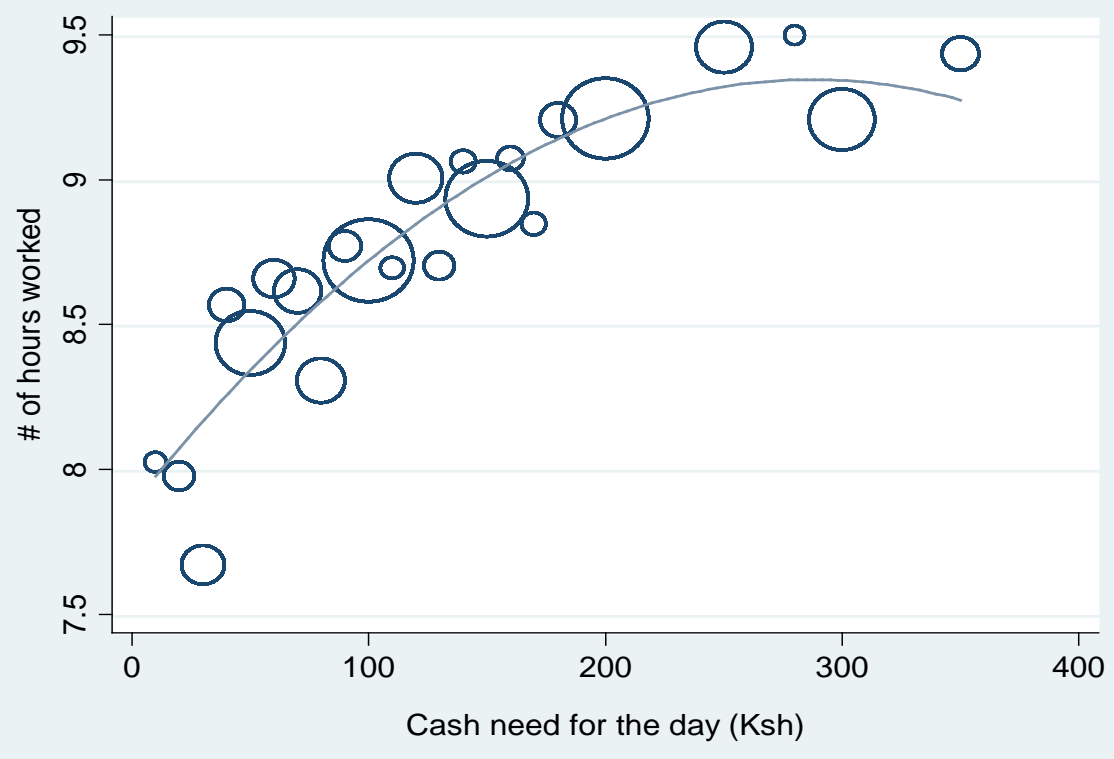

$\circ$ Mean Quadratic fit

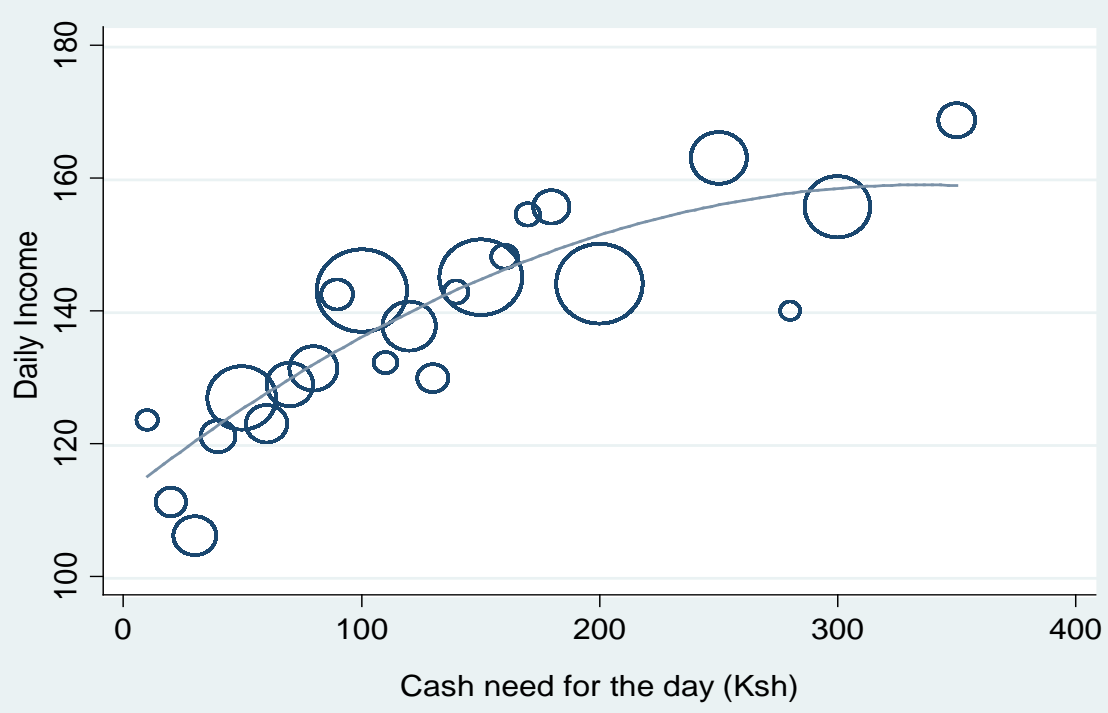

Notes: Each circle corresponds to an average across at least 50 man-days. Size of circle indicates number of man-days. 
Figure 2. Coefficients from Hazard Regressions

Panel A. All Cash Need Amounts

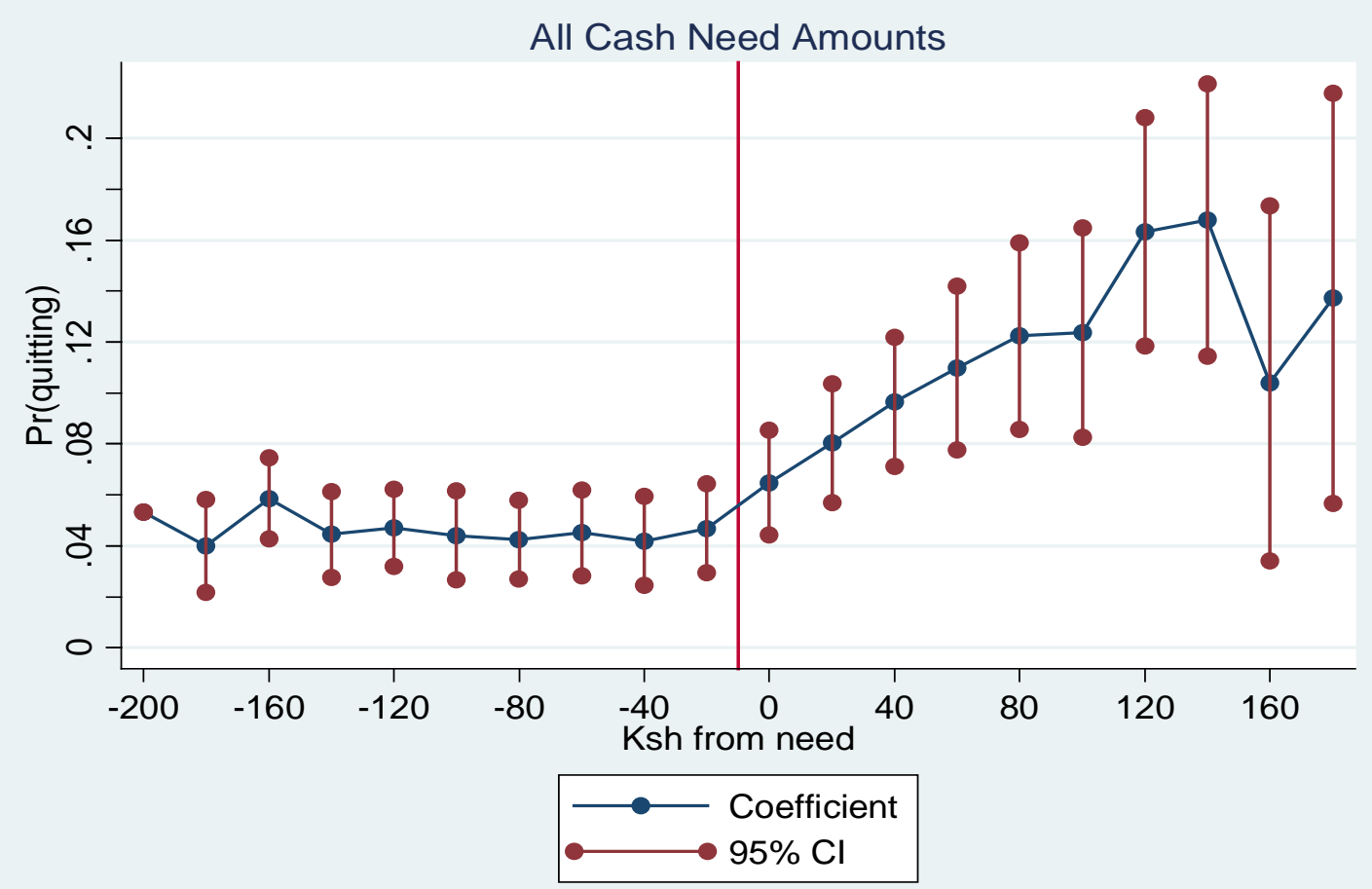

Panel B. By Need Size
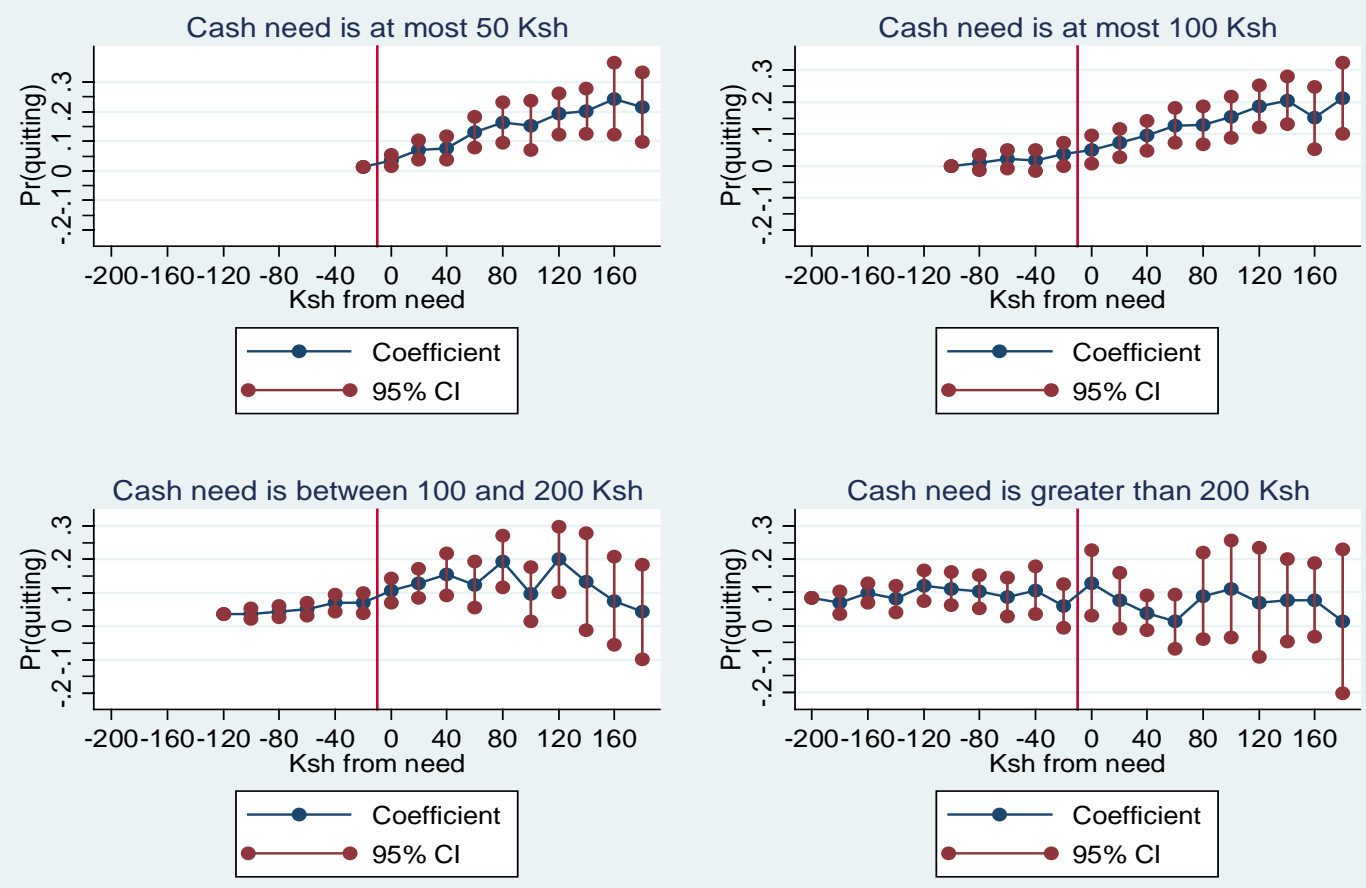
Figure 3. Hazard Regressions: Heterogeneity
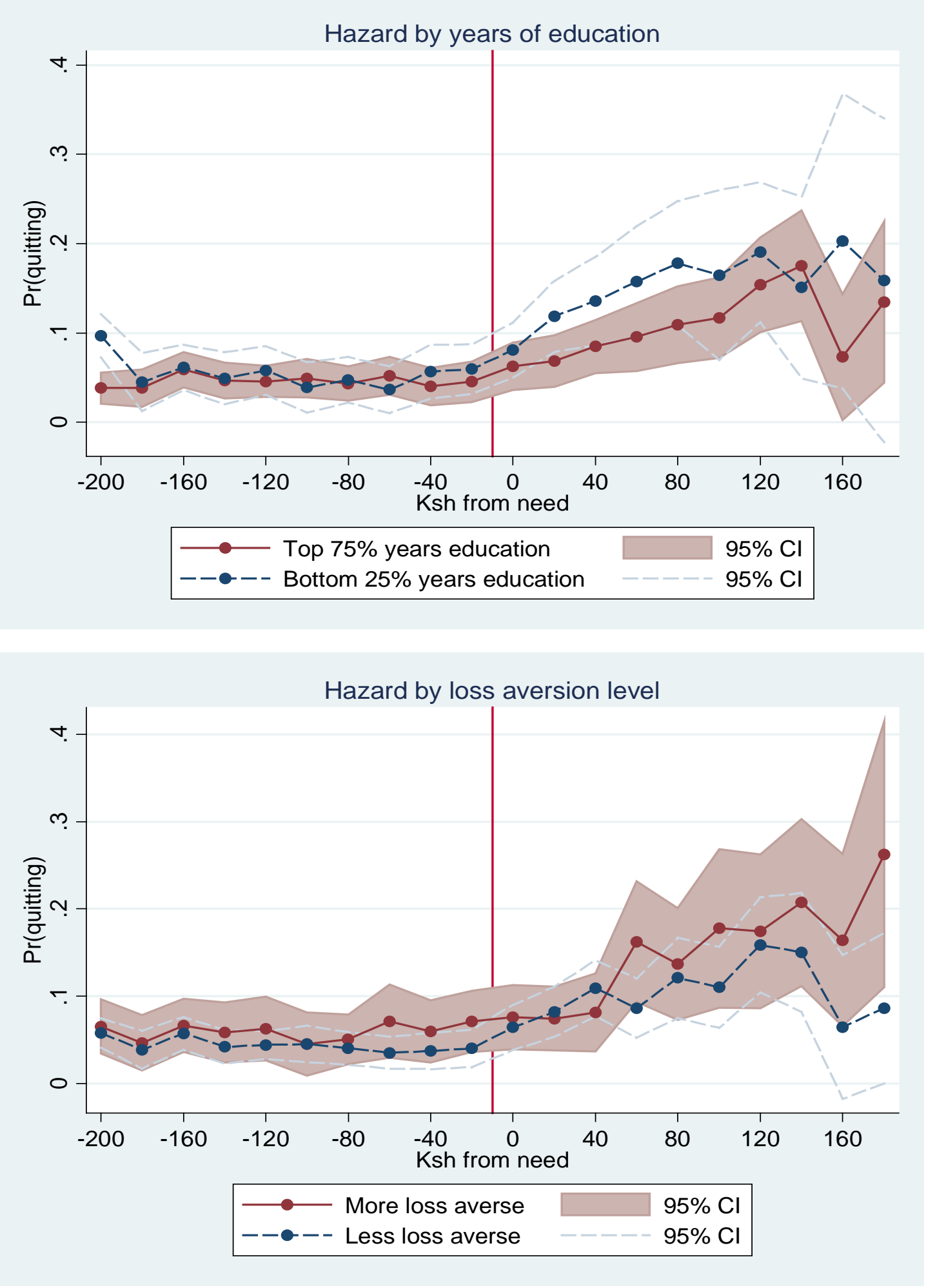
Figure 4. Potential Income Gain from Alternative Labor Supply Behaviors

Panel A. Fixed Hours

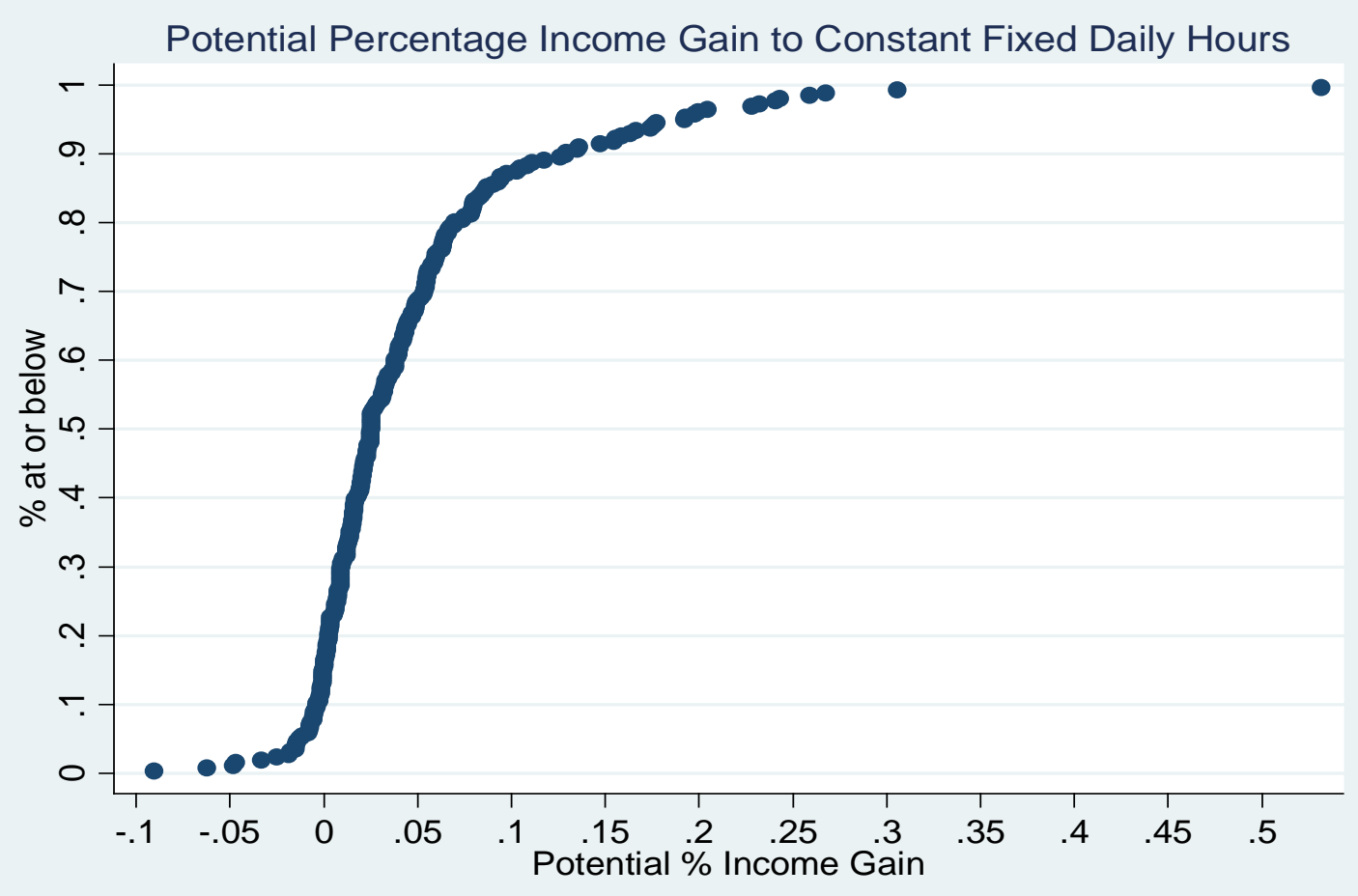

Panel B. Wage Elasticity of 0.15

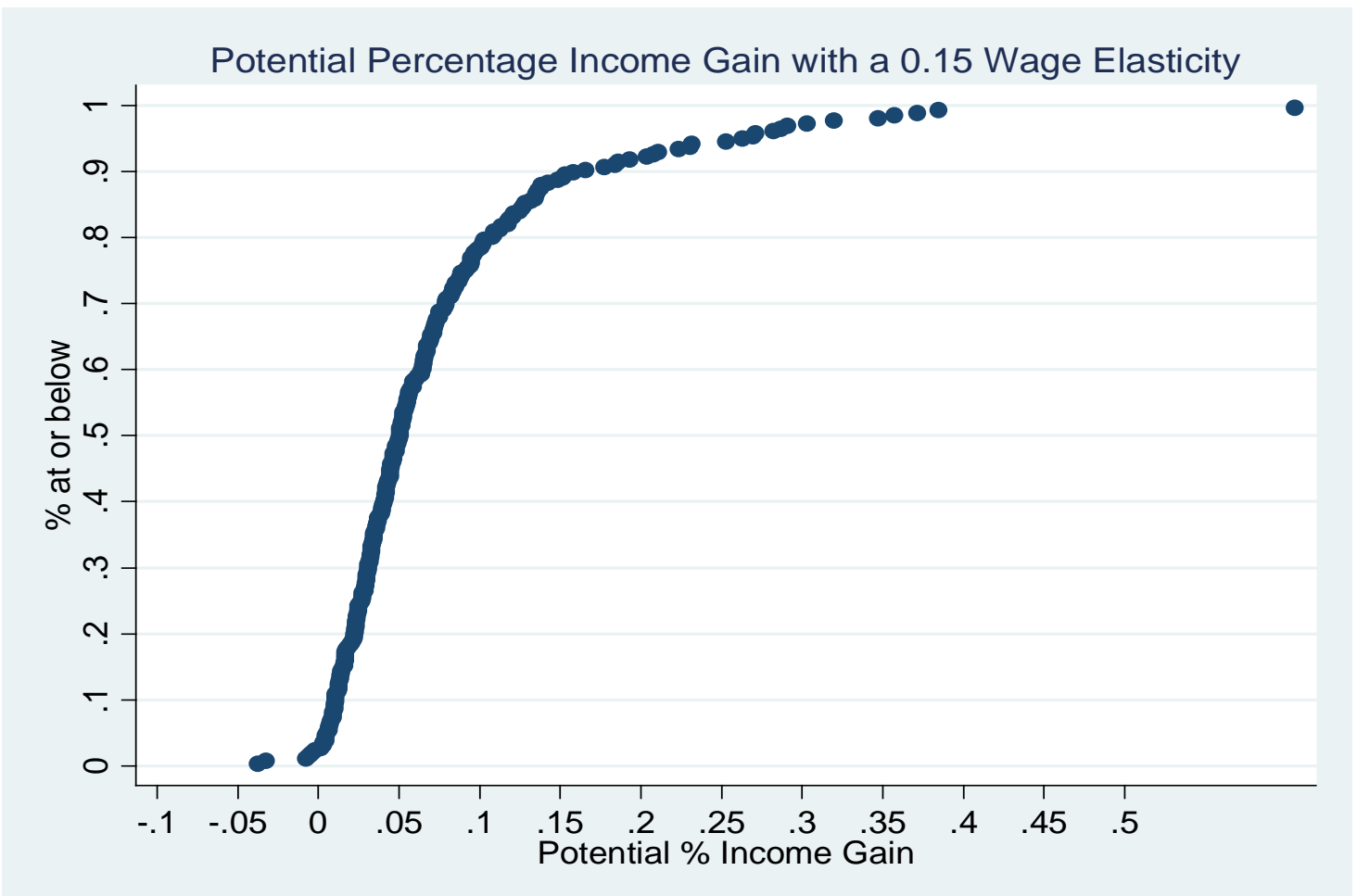

This graph shows the cumulative distribution function, across all 256 individuals in our sample, of the variable "potential \% income gain", which was constructed as follows. For each individual, we divided their total hours worked over the study period by the number of days worked and call this the "fixed hours target". We then compute how much they would have earned on each day worked, if they had worked exactly as many hours as the fixed hours target, at the average wage rate observed that day among other individuals working in the same market. We then sum up the total earnings under that fixed hours target rule, and compare it to the total actually earned. 


\begin{tabular}{|c|c|c|}
\hline & $\begin{array}{c}(1) \\
\text { Mean } \\
\end{array}$ & $\begin{array}{c}\text { (2) } \\
\text { Std. Dev. }\end{array}$ \\
\hline \multicolumn{3}{|l|}{ Panel A. Demographic Information } \\
\hline Age & 33.06 & 8.11 \\
\hline Married & 0.96 & 0.19 \\
\hline Number of Children & 3.40 & 2.27 \\
\hline Education & 6.78 & 2.22 \\
\hline Value of Durable Goods Owned (in Ksh) & 11097.76 & 8381.72 \\
\hline Value of Animals Owned (in Ksh) & 6933.44 & 9858.87 \\
\hline Acres of land owned & 1.42 & 1.44 \\
\hline Total Bike-Taxi Income in Week Prior to Survey (in Ksh) & 573.52 & 340.41 \\
\hline Has another regular source of income & 0.15 & 0.36 \\
\hline If yes, income in average week from other income & 576.43 & 524.80 \\
\hline Has seasonal income & 0.20 & 0.40 \\
\hline If yes, income in normal season & 6631.84 & 10702.20 \\
\hline \multicolumn{3}{|l|}{ Panel B. Financial Access } \\
\hline Participates in ROSCA & 0.75 & 0.43 \\
\hline If yes, number of ROSCAs & 1.06 & 0.84 \\
\hline If yes, ROSCA contributions in last year (in Ksh) & 5972.35 & 7880.52 \\
\hline Owns Bank Account & 0.32 & 0.47 \\
\hline Received gift/loan in past 3 months & 0.24 & 0.43 \\
\hline If yes, amount & 0.29 & 0.45 \\
\hline Gave gift/loan in past 3 months & 2204.22 & 2348.50 \\
\hline If yes, amount & 1195.88 & 1877.05 \\
\hline \multicolumn{3}{|l|}{ If needed 1,000 Ksh right away, would: } \\
\hline Use savings & 0.10 & 0.30 \\
\hline Sell asset(s) & 0.34 & 0.48 \\
\hline Work more & 0.12 & 0.32 \\
\hline Get gift/loan from friends/ relatives & 0.47 & 0.50 \\
\hline Get loan from ROSCA & 0.21 & 0.41 \\
\hline \multicolumn{3}{|l|}{ Panel C. Health } \\
\hline Health Problems Index (scale 1-5) ${ }^{1}$ & 1.97 & 0.68 \\
\hline Average Score on Activities of Daily Living (scale $1-5)^{2}$ & 1.51 & 0.39 \\
\hline Overall, how would you rate your health (scale $1-5) ?^{3}$ & 2.59 & 0.73 \\
\hline Missed work due to illness in past month & 0.39 & 0.49 \\
\hline If yes, number of days missed & 2.20 & 1.80 \\
\hline Early Bird: Starts work before 8 am on median work day & 0.51 & 0.50 \\
\hline \multicolumn{3}{|l|}{ Panel D. Small-Stakes Risk Aversion and Loss Aversion } \\
\hline Amount invested (out of $100 \mathrm{Ksh}$ ) in Risky Asset ${ }^{4}$ & 56.19 & 26.02 \\
\hline More loss averse: Refuses the $50-50$ gamble (win 30 or lose 10 ) & 0.28 & 0.45 \\
\hline More loss averse: Refuses the $50-50$ gamble (win 120 or lose 50 ) & 0.58 & 0.50 \\
\hline
\end{tabular}

Notes: All variables but "early bird" are from the baseline. There are 245 observations in the baseline.

Exchange rate was roughly $70 \mathrm{Ksh}$ to US $\$ 1$ during the study period.

${ }^{1}$ The index refers to severity of pain and difficulty in performing activities of daily living. The index ranges between 1 and 5 , where $1=$ none, $2=$ mild, $3=$ moderate, $4=$ severe and $5=$ extreme. It is composed of 4 self-assessed measures shown in Table A1.

${ }^{2}$ Average score across all activities shown in Table A1. Codes are the same as above.

${ }^{3}$ Codes: 1-excellent, 2-good, 3-OK, 4-poor, 5-very poor.

${ }^{4}$ The risky asset paid off 4 times the amount invested with probability 0.5 , and 0 with probability 0.5 . 


\begin{tabular}{|c|c|c|c|}
\hline (1) & (2) & (3) & (4) \\
\hline Mean & Std. Dev. & $\begin{array}{c}\text { \# of } \\
\text { Observations } \\
\text { (Individual-days) }\end{array}$ & \# of Individuals \\
\hline
\end{tabular}

\section{A. Labor Supply}

Worked today

If yes, total income (Ksh)

0.74

144.70

If yes, total hours

Received income from some other source

8.95

0.24

If yes, amount earned (Ksh)

79.59

3.32
0.44

93.72

2.77

0.43

485.39

2.26
12466

9192

8583

8159

1971

1990
257

257

256

248

217

217

\section{B. Is there something in particular that you need money for today?}

Yes

If yes, amount (Ksh)

\section{Cash outflows}

Respondent Sick

Somebody in household sick

School fees due

Funeral

Had to make repairs to bike

If yes, amount spent on repairs (Ksh)

Made a ROSCA contribution

\section{Other Cash Flows}

Somebody asked for money

If yes, respondent gave money

Got money from somebody

Got money from spouse

Gave money to spouse

Made withdrawal from home savings

Made withdrawal from bank savings

Received lump sum payment from regular customer

Received a ROSCA payout

\section{E. Individual-level variables}

Ever rented bike

Ever got lump sum payment from regular customer

\subsection{8}

203.74

0.18

0.10

0.02

0.05

0.21

77.63

0.15

0.02

1.00

0.02

0.01

0.12

0.04

0.01

0.01

0.01

0.18

0.27
0.32

340.44

0.38

0.29

0.13

0.21

0.41

92.65

0.36

0.14

0.07

0.14

0.10

0.32

0.20

0.09

0.11

0.11

0.38

0.45
12466

10560

12461

12466

9732

9783

9658

2012

10674

9765

201

9779

9726

9721

8469

3141

9751

9759

13417

13443
257

257

257

257

256

256

255

253

257

256

109

256

256

256

249

77

256

256

Notes: Exchange rate was roughly $75 \mathrm{Ksh}$ to $\$ 1$ US during the sample period. 
Table 3. Determinants of Cash Need for the Day

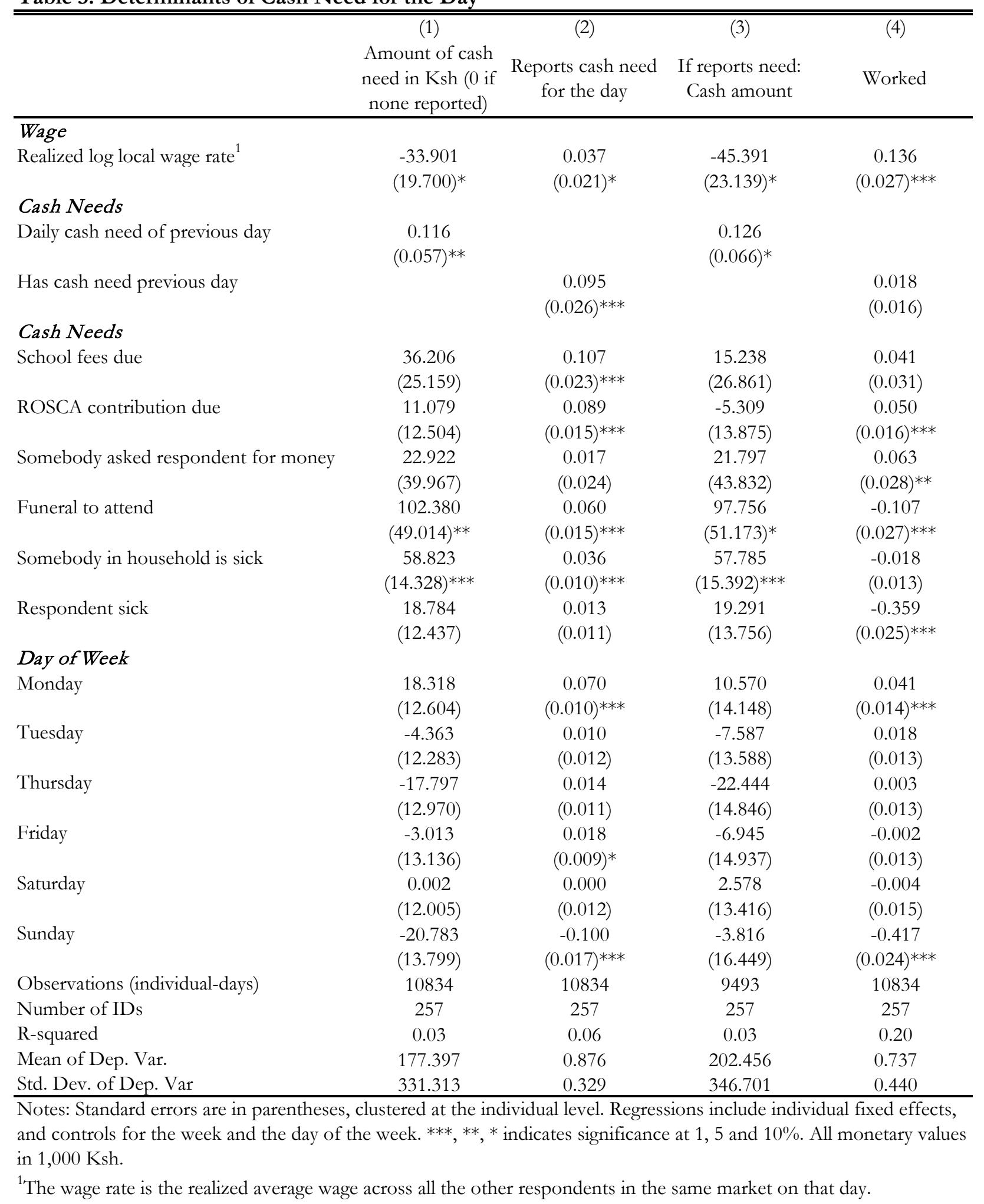


Table 4. Effect of Daily Cash Need on Labor Supply

\begin{tabular}{|c|c|c|c|c|c|c|c|c|c|c|c|c|}
\hline & (1) & (2) & (3) & (4) & (5) & (6) & (7) & $(8)$ & (9) & $(10)$ & $(11)$ & $(12)$ \\
\hline & & & \multicolumn{10}{|c|}{ If worked: } \\
\hline & \multicolumn{2}{|c|}{ Worked Today } & \multicolumn{2}{|c|}{ Total Income } & \multicolumn{2}{|c|}{ Total income } & \multicolumn{2}{|c|}{ Number of passengers } & \multicolumn{2}{|c|}{ Total hours } & \multicolumn{2}{|c|}{ Passengers per hour } \\
\hline Has a need & $\begin{array}{c}0.189 \\
(0.022)^{* * *}\end{array}$ & & $\begin{array}{c}22.784 \\
(4.144)^{* * *}\end{array}$ & & $\begin{array}{l}-5.796 \\
(4.318)\end{array}$ & & $\begin{array}{c}0.011 \\
(0.092)\end{array}$ & & $\begin{array}{l}-0.097 \\
(0.113)\end{array}$ & & $\begin{array}{c}0.008 \\
(0.011)\end{array}$ & \\
\hline If has a need: $\log$ (cash need) & & $\begin{array}{l}-0.009 \\
(0.008)\end{array}$ & & $\begin{array}{c}11.670 \\
(1.977)^{* * *}\end{array}$ & & $\begin{array}{c}17.031 \\
(1.990)^{* * *}\end{array}$ & & $\begin{array}{c}0.232 \\
(0.039)^{* * *}\end{array}$ & & $\begin{array}{c}0.274 \\
(0.054)^{* * *}\end{array}$ & & $\begin{array}{c}0.000 \\
(0.005)\end{array}$ \\
\hline Realized log (local wage rate) & $\begin{array}{c}0.111 \\
(0.026)^{* * *}\end{array}$ & $\begin{array}{c}0.107 \\
(0.029)^{* * *}\end{array}$ & $\begin{array}{c}57.780 \\
(6.469)^{* * *}\end{array}$ & $\begin{array}{c}59.614 \\
(7.293)^{* * *}\end{array}$ & $\begin{array}{c}57.302 \\
(6.899)^{* * *}\end{array}$ & $\begin{array}{c}57.070 \\
(7.015)^{* * *}\end{array}$ & $\begin{array}{c}0.907 \\
(0.145)^{* * *}\end{array}$ & $\begin{array}{c}0.973 \\
(0.140)^{* * *}\end{array}$ & $\begin{array}{c}-0.595 \\
(0.248)^{* *}\end{array}$ & $\begin{array}{c}-0.536 \\
(0.212)^{* *}\end{array}$ & $\begin{array}{c}0.153 \\
(0.024)^{* * *}\end{array}$ & $\begin{array}{c}0.154 \\
(0.026)^{* * *}\end{array}$ \\
\hline Observations (individual-days) & 12429 & 10531 & 12429 & 10531 & 9163 & 8134 & 9163 & 8134 & 8563 & 7635 & 8563 & 7635 \\
\hline Number of IDs & 257 & 257 & 257 & 257 & 257 & 257 & 257 & 257 & 256 & 256 & 256 & 256 \\
\hline R-squared & 0.21 & 0.17 & 0.12 & 0.11 & 0.03 & 0.06 & 0.04 & 0.05 & 0.03 & 0.04 & 0.03 & 0.03 \\
\hline Mean of Dep. Var. & 0.737 & 0.772 & 106.680 & 111.184 & 144.705 & 143.949 & 4.410 & 4.414 & 8.952 & 8.935 & 0.538 & 0.538 \\
\hline Std. Dev. of Dep. Var & 0.440 & 0.419 & 102.646 & 100.702 & 93.750 & 91.721 & 2.153 & 2.146 & 2.769 & 2.763 & 0.310 & 0.311 \\
\hline
\end{tabular}

Notes: Regressions are at the individual-day level. All regressions include individual fixed effects and controls for the week the day of week. Regressions also control for whether it rained that day and whether the respondent reports being sick that day. We have fewer observations for the hour variables since the data was misrecorded in some casesStandard errors are in parentheses, clustered at the individual level. ***, **, * indicates significance at 1,5 and $10 \%$. 
Table 5. Parametric Hazard Regressions

\begin{tabular}{|c|c|c|c|c|c|}
\hline & (1) & (2) & (3) & (4) & (5) \\
\hline & \multicolumn{5}{|c|}{ Dependent variable: quit after dropping off passenger } \\
\hline & \multirow[b]{2}{*}{$\begin{array}{c}\text { Baseline } \\
\text { Specification }\end{array}$} & \multicolumn{4}{|c|}{ Including interactions with: } \\
\hline & & $\begin{array}{l}\text { Top } 75 \% \\
\text { years of } \\
\text { education }\end{array}$ & $\begin{array}{c}\text { Top 50\% } \\
\text { years of } \\
\text { education }\end{array}$ & $\begin{array}{c}\text { Years of } \\
\text { Education }\end{array}$ & Loss Averse \\
\hline \multicolumn{6}{|l|}{ Level Effects } \\
\hline \multirow[t]{2}{*}{ Cumulative Hours Worked } & -0.08 & -0.083 & -0.084 & -0.161 & -0.084 \\
\hline & $(0.04)^{* *}$ & $(0.040)^{* *}$ & $(0.040)^{* *}$ & $(0.117)$ & $(0.040)^{* *}$ \\
\hline \multirow[t]{2}{*}{ Cumulative Hours Worked Squared } & 0.36 & 0.362 & 0.363 & 0.496 & 0.363 \\
\hline & $(0.04)^{* * *}$ & $(0.039)^{* * *}$ & $(0.039)^{* * *}$ & $(0.122)^{* * *}$ & $(0.039)^{* * *}$ \\
\hline \multirow{2}{*}{ Distance from need } & 0.11 & 0.109 & 0.109 & 0.123 & 0.118 \\
\hline & $(0.090)$ & $(0.088)$ & $(0.088)$ & $(0.089)$ & $(0.088)$ \\
\hline \multirow[t]{2}{*}{ Over need } & 0.04 & 0.066 & 0.054 & 0.078 & 0.086 \\
\hline & $(0.01)^{* * *}$ & $(0.018)^{* * *}$ & $(0.012)^{* * *}$ & $(0.035)^{* *}$ & $(0.037)^{* *}$ \\
\hline \multirow[t]{2}{*}{ Distance from need $*$ over need } & 0.02 & -0.026 & -0.019 & -0.087 & 0.054 \\
\hline & $(0.120)$ & $(0.267)$ & $(0.186)$ & $(0.560)$ & $(0.587)$ \\
\hline \multicolumn{6}{|l|}{ Interaction Effects } \\
\hline Distance from need & & -0.01 & -0.01 & -0.001 & -0.001 \\
\hline * Interacted Variable & & $(0.014)$ & $(0.016)$ & $(0.002)$ & $(0.003)$ \\
\hline Over need & & -0.035 & -0.032 & -0.005 & -0.006 \\
\hline * Interacted Variable & & $(0.021)^{*}$ & $(0.019)^{*}$ & $(0.005)$ & $(0.005)$ \\
\hline Distance from need $*$ over need & & 0.072 & 0.092 & 0.017 & -0.004 \\
\hline * Interacted Variable & & $(0.330)$ & $(0.281)$ & $(0.072)$ & $(0.076)$ \\
\hline Observations (individual-days) & 34984 & 34311 & 34311 & 34311 & 34311 \\
\hline Number of IDs & 257 & 244 & 244 & 244 & 244 \\
\hline R-squared & 0.15 & 0.16 & 0.16 & 0.16 & 0.16 \\
\hline Mean of Dep. Var. & 0.09 & 0.089 & 0.089 & 0.089 & 0.089 \\
\hline
\end{tabular}

Notes: All regressions include individual fixed effects and controls for the week the day of week. Standard errors in parentheses. We do not include interactions between hours worked and education because when we do so we cannot reject equality. $* * *$, and $* * *$ indicate significance at $10 \%, 5 \%$, and $1 \%$ respectively. 


\begin{tabular}{lcccc}
\hline \hline & $(1)$ & $(2)$ & $(3)$ & $(4)$ \\
\cline { 3 - 5 } & & & If worked: & \\
\cline { 2 - 5 } & & & & \\
& $\begin{array}{c}\text { Worked } \\
\text { Today }\end{array}$ & $\begin{array}{c}\text { Total } \\
\text { income }\end{array}$ & Total hours & $\begin{array}{c}\text { Time ended } \\
\text { work }\end{array}$ \\
\cline { 2 - 5 } Won big lottery prize today & & & & -0.06 \\
& 0.011 & 5.457 & 0.092 & $(0.105)$ \\
Won big lottery prize yesterday & 0.025 & $(4.975)$ & $(0.153)$ & 0.111 \\
& $(0.024)$ & $(3.394)$ & $(0.148)$ & $(0.102)$ \\
Observations (individual-days) & 10703 & 7924 & 7485 & 7538 \\
Number of IDs & 256 & 256 & 256 & 256 \\
R-squared & 0.24 & 0.21 & 0.04 & 0.01 \\
Mean of Dep. Var. & 0.74 & 145.718 & 8.921 & 17.433 \\
Std. Dev. of Dep. Var & 0.438 & 95.313 & 2.76 & 1.882 \\
\hline
\end{tabular}

Notes: Regressions are at the individual-day level. Standard errors are in parentheses, clustered at the individual level. Regressions include individual fixed effects, all the variables shown in Table 3 , and controls for the week the day of week.. ***, **,* indicates significance at 1,5 and $10 \%$. 
Table 7. Daily Needs, Income Targets, and Hours Targets

\begin{tabular}{|c|c|c|c|c|}
\hline & (1) & (2) & (3) & (4) \\
\hline \multicolumn{5}{|l|}{ Dependent variable $=1$ if quit work for the day } \\
\hline \multirow{2}{*}{ Cumulative Hours Worked (Units = Hours / 10) } & -0.03 & -0.07 & -0.10 & -0.12 \\
\hline & $(0.04)$ & $(0.04)^{*}$ & $(0.04)^{* * *}$ & $(0.04)^{* * *}$ \\
\hline \multirow[t]{2}{*}{ Cumulative Hours Worked Squared } & & & 0.32 & 0.35 \\
\hline & & & $(0.04)^{* * *}$ & $(0.04)^{* * *}$ \\
\hline \multirow[t]{2}{*}{ Cumulative Income Earned (Units = Ksh / 1000) } & 0.16 & 0.06 & 0.63 & 0.46 \\
\hline & $(0.10)$ & $(0.10)$ & $(0.11)^{* * *}$ & $(0.11)^{* * *}$ \\
\hline \multirow[t]{2}{*}{ Cumulative Income Earned Squared } & & & -0.78 & -0.65 \\
\hline & & & $(0.19)^{* * *}$ & $(0.19)^{* * *}$ \\
\hline \multirow[t]{2}{*}{ Cumulative Hours $>$ Estimated Target } & 0.08 & 0.07 & 0.08 & 0.07 \\
\hline & $(0.01)^{* * *}$ & $(0.01)^{* * *}$ & $(0.01)^{* * *}$ & $(0.01)^{* * *}$ \\
\hline \multirow[t]{2}{*}{ Cumulative Income $>$ Estimated Target } & 0.03 & 0.03 & 0.02 & 0.02 \\
\hline & $(0.01)^{* * *}$ & $(0.01)^{* * *}$ & $(0.01)^{* * *}$ & $(0.01)^{* * *}$ \\
\hline \multirow[t]{2}{*}{ Over need } & & 0.04 & & 0.03 \\
\hline & & $(0.01)^{* * *}$ & & $(0.01)^{* * *}$ \\
\hline Observations & 40670 & 36070 & 40670 & 36070 \\
\hline Number of bodas & 257 & 257 & 257 & 257 \\
\hline R-squared & 0.15 & 0.16 & 0.15 & 0.16 \\
\hline Mean of dependent variable & 0.09 & 0.09 & 0.09 & 0.09 \\
\hline
\end{tabular}

Notes: These estimates follow Table 3 Crawford and Meng (2011). Targets are estimated as average daily income or hours on days up to but not including the day in question. Targets are estimated by day of the week. All regressions include individual fixed effects and controls for the week the day of week. Standard errors clustered at the individual level in parentheses. *, **, and *** indicate significance at 10\%, 5\%, and 1\% respectively. 
Table 8. Education and Capitalizing on High Wage Days

\begin{tabular}{|c|c|c|c|c|c|c|c|}
\hline & (1) & (2) & (3) & $\begin{array}{c}(4) \\
\text { If worked: }\end{array}$ & (5) & (6) & (7) \\
\hline & $\begin{array}{l}\text { Worked } \\
\text { Today }\end{array}$ & $\begin{array}{c}\text { Total } \\
\text { Income }\end{array}$ & $\begin{array}{c}\text { Total } \\
\text { income }\end{array}$ & $\begin{array}{c}\text { Number of } \\
\text { passengers }\end{array}$ & Total hours & $\begin{array}{l}\text { Log own } \\
\text { wage rate }\end{array}$ & $\begin{array}{c}\text { Passengers } \\
\text { per hour }\end{array}$ \\
\hline Has a need & $\begin{array}{c}0.175 \\
(0.026)^{* * *}\end{array}$ & $\begin{array}{c}19.943 \\
(6.110)^{* * *}\end{array}$ & $\begin{array}{l}-5.269 \\
(7.553)\end{array}$ & $\begin{array}{c}0.01 \\
(0.148)\end{array}$ & $\begin{array}{l}-0.176 \\
(0.180)\end{array}$ & $\begin{array}{c}0.006 \\
(0.040)\end{array}$ & $\begin{array}{c}0.012 \\
(0.014)\end{array}$ \\
\hline Has a need $*$ top $75 \%$ of education distribution & $\begin{array}{c}0.025 \\
(0.041)\end{array}$ & $\begin{array}{c}5.059 \\
(8.377)\end{array}$ & $\begin{array}{l}-1.826 \\
(8.826)\end{array}$ & $\begin{array}{l}-0.036 \\
(0.183)\end{array}$ & $\begin{array}{c}0.132 \\
(0.222)\end{array}$ & $\begin{array}{l}-0.026 \\
(0.049)\end{array}$ & $\begin{array}{l}-0.007 \\
(0.022)\end{array}$ \\
\hline Big day (wage is over median) & $\begin{array}{c}0.023 \\
(0.015)\end{array}$ & $\begin{array}{c}7.785 \\
(4.146)^{*}\end{array}$ & $\begin{array}{c}5.132 \\
(4.463)\end{array}$ & $\begin{array}{l}-0.026 \\
(0.092)\end{array}$ & $\begin{array}{c}-0.11 \\
(0.128)\end{array}$ & $\begin{array}{c}0.028 \\
(0.022)\end{array}$ & $\begin{array}{c}0.007 \\
(0.011)\end{array}$ \\
\hline Big day $*$ top $75 \%$ of education distribution & $\begin{array}{c}0.022 \\
(0.020)\end{array}$ & $\begin{array}{c}11.504 \\
(5.881)^{*}\end{array}$ & $\begin{array}{l}8.653 \\
(6.251)\end{array}$ & $\begin{array}{c}0.133 \\
(0.117)\end{array}$ & $\begin{array}{c}0.023 \\
(0.155)\end{array}$ & $\begin{array}{c}0.062 \\
(0.031)^{*}\end{array}$ & $\begin{array}{c}0.024 \\
(0.015)^{*}\end{array}$ \\
\hline Observations (individual-days) & 11982 & 11982 & 8916 & 8916 & 8380 & 8378 & 8380 \\
\hline Number of IDs & 243 & 243 & 243 & 243 & 243 & 243 & 243 \\
\hline ID fixed effects & Yes & Yes & Yes & Yes & Yes & Yes & Yes \\
\hline R-squared & 0.20 & 0.11 & 0.02 & 0.03 & 0.03 & 0.02 & 0.02 \\
\hline Mean of Dep. Var. & 0.744 & 108.246 & 145.469 & 4.422 & 8.953 & 2.691 & 0.537 \\
\hline Std. Dev. of Dep. Var & 0.436 & 103.329 & 94.517 & 2.162 & 2.767 & 0.581 & 0.310 \\
\hline
\end{tabular}


Table 9. Relationship between hours worked and endline health

\begin{tabular}{|c|c|c|c|c|}
\hline \multirow{4}{*}{ Log (total hours over sample period) } & $(1)$ & (2) & & (4) \\
\hline & \multicolumn{2}{|c|}{ Sick in last week of logs } & \multicolumn{2}{|c|}{$\begin{array}{c}\text { Missed work due to sickness in last } \\
\text { week of logs }\end{array}$} \\
\hline & 0.03 & 0.03 & 0.01 & 0.01 \\
\hline & $(0.03)$ & $(0.03)$ & $(0.03)$ & $(0.02)$ \\
\hline \multirow[t]{2}{*}{ Log (std. deviation daily hours over sample period) } & 0.18 & 0.14 & 0.12 & 0.08 \\
\hline & $(0.083)^{* *}$ & $(0.084)^{*}$ & $(0.069)^{*}$ & $(0.07)$ \\
\hline \multirow[t]{2}{*}{ Health is worse than average at baseline } & & 0.06 & & 0.12 \\
\hline & & $(0.06)$ & & $(0.049)^{* *}$ \\
\hline Missed work at least once due to sickness & & 0.09 & & 0.02 \\
\hline in month prior to baseline & & $(0.06)$ & & $(0.05)$ \\
\hline Observations (one per individual) & 252 & 252 & 252 & 252 \\
\hline R-squared & 0.03 & 0.06 & 0.02 & 0.05 \\
\hline Mean of Dep. Var. & 0.25 & 0.25 & 0.15 & 0.15 \\
\hline Std. Dev. of Dep. Var & 0.43 & 0.43 & 0.36 & 0.36 \\
\hline
\end{tabular}

Notes: Regressions include controls for the total number of days covered in the logbooks. Standard errors are in parentheses, clustered at the individual level. ***, **, * indicates significance at 1,5 and $10 \%$. 


\begin{tabular}{|c|c|c|c|c|c|c|}
\hline & $\begin{array}{c}(1) \\
\text { None } \\
\end{array}$ & $\begin{array}{c}(2) \\
\text { Mild } \\
\end{array}$ & $\begin{array}{c}(3) \\
\text { Moderate } \\
\end{array}$ & $\begin{array}{c}(4) \\
\text { Severe } \\
\end{array}$ & $\begin{array}{c}(5) \\
\text { Extreme }\end{array}$ & $\begin{array}{l}(6) \\
\mathrm{N}\end{array}$ \\
\hline * In the past 30 days, how much of bodily aches or pains did you have? & 0.32 & 0.43 & 0.20 & 0.04 & 0.02 & 243 \\
\hline * How much difficulty do you have in your daily life because of your pain & 0.16 & 0.55 & 0.25 & 0.04 & 0.01 & 182 \\
\hline * In the past 30 days, how much discomfort did you have? & 0.14 & 0.55 & 0.27 & 0.03 & 0.03 & 180 \\
\hline \multicolumn{7}{|l|}{ How much difficulty have you experienced in the past 30 days with...? } \\
\hline Concentrating or remembering things & 0.55 & 0.20 & 0.18 & 0.05 & 0.02 & 244 \\
\hline Learning a new task & 0.64 & 0.22 & 0.12 & 0.02 & 0.01 & 245 \\
\hline Sleeping & 0.74 & 0.15 & 0.10 & 0.01 & 0.00 & 242 \\
\hline Feeling tired and / or not having enercy during the day & 0.45 & 0.33 & 0.19 & 0.02 & 0.01 & 244 \\
\hline Seeing or recognizing someone you know from across the road & 0.82 & 0.07 & 0.10 & 0.01 & 0.01 & 239 \\
\hline Seeing or recognizing someone you know from your arm's length & 0.88 & 0.06 & 0.05 & 0.01 & 0.01 & 244 \\
\hline Sitting for long periods of time & 0.80 & 0.08 & 0.10 & 0.01 & 0.01 & 244 \\
\hline Standing up from sitting down & 0.80 & 0.10 & 0.08 & 0.01 & 0.00 & 242 \\
\hline Stooping, Kneeling or crouching & 0.75 & 0.16 & 0.08 & 0.01 & 0.01 & 245 \\
\hline Picking things up with your fingers & 0.93 & 0.05 & 0.02 & 0.02 & 0.02 & 245 \\
\hline Extending arms above shoulder level & 0.85 & 0.10 & 0.03 & 0.01 & 0.00 & 241 \\
\hline Concentratin on something for more than 10 minutes & 0.71 & 0.20 & 0.09 & 0.01 & 0.01 & 245 \\
\hline * Overall, how much did these difficulties interfere with your life? & 0.31 & 0.45 & 0.22 & 0.01 & 0.00 & 245 \\
\hline
\end{tabular}

* Overall, how much did these difficulties interfere with your life?

Data source: background survey.

* Items included in the Health Problems Index shown in Table 1. 
Appendix Table A2. Relationship Between Reported Cash Needs and Actual Expenditures

\begin{tabular}{|c|c|c|c|c|c|c|c|c|c|c|}
\hline & (1) & (2) & (3) & (4) & $(5)$ & (6) & $(7)$ & (8) & (9) & $(10)$ \\
\hline & \multicolumn{10}{|c|}{ Reported need of: } \\
\hline & \multicolumn{2}{|c|}{ ROSCA payment } & \multicolumn{2}{|c|}{ School Fees } & \multicolumn{2}{|c|}{ Funeral Expenses } & \multicolumn{2}{|c|}{ Repaired bike } & \multicolumn{2}{|c|}{ Repaid a Loan } \\
\hline Made ROSCA deposit & $\begin{array}{c}0.55 \\
(0.026)^{* * *}\end{array}$ & $\begin{array}{c}0.55 \\
(0.027)^{* * *}\end{array}$ & & & & & & & & \\
\hline Will make ROSCA deposit tomorrow & & $\begin{array}{c}-0.04 \\
(0.018)^{* *}\end{array}$ & & & & & & & & \\
\hline Will make ROSCA deposit in 2 days & & $\begin{array}{c}-0.05 \\
(0.014)^{* * *}\end{array}$ & & & & & & & & \\
\hline Paid school fees & & & $\begin{array}{c}0.56 \\
(0.044)^{* * *}\end{array}$ & $\begin{array}{c}0.59 \\
(0.043)^{* * *}\end{array}$ & & & & & & \\
\hline Will pay school fees tomorrow & & & & $\begin{array}{c}0.03 \\
(0.03)\end{array}$ & & & & & & \\
\hline Will pay school fees in 2 days & & & & $\begin{array}{c}0.02 \\
(0.02)\end{array}$ & & & & & & \\
\hline Contributed to funeral & & & & & $\begin{array}{c}0.49 \\
(0.033)^{* * *}\end{array}$ & $\begin{array}{c}0.50 \\
(0.034)^{* * *}\end{array}$ & & & & \\
\hline Will contribute to funeral tomorrow & & & & & & $\begin{array}{c}0.02 \\
(0.02)\end{array}$ & & & & \\
\hline Will contribute to funeral in 2 days & & & & & & $\begin{array}{c}0.01 \\
(0.02)\end{array}$ & & & & \\
\hline Made repairs to bicycle & & & & & & & 0.70 & 0.70 & & \\
\hline Will make repairs to bicycle tomorrow & & & & & & & $(0.014)^{* * *}$ & $\begin{array}{c}(0.016)^{* * *} \\
-0.01 \\
(0.01)\end{array}$ & & \\
\hline Will make repairs to bicycle in 2 days & & & & & & & & $\begin{array}{c}0.00 \\
(0.01)\end{array}$ & & \\
\hline Repaid loan & & & & & & & & & $\begin{array}{c}0.26 \\
(0.072)^{* * *}\end{array}$ & $\begin{array}{c}0.25 \\
(0.068)^{* * *}\end{array}$ \\
\hline Will repay loan tomorrow & & & & & & & & & & $\begin{array}{c}0.07 \\
(0.05)\end{array}$ \\
\hline Will repay loan in 2 days & & & & & & & & & & $\begin{array}{c}0.04 \\
(0.04)\end{array}$ \\
\hline Observations & 8773 & 7473 & 8802 & 7504 & 8839 & 7549 & 8739 & 7394 & 7821 & 6692 \\
\hline Number of IDs & 253 & 252 & 253 & 252 & 253 & 252 & 253 & 252 & 243 & 242 \\
\hline R-squared & 0.26 & 0.25 & 0.19 & 0.21 & 0.20 & 0.21 & 0.47 & 0.47 & 0.07 & 0.07 \\
\hline Mean of dependent variable & 0.19 & 0.19 & 0.03 & 0.03 & 0.06 & 0.06 & 0.25 & 0.25 & 0.01 & 0.01 \\
\hline
\end{tabular}

Notes: Regressions include individual fixed effects, as well as controls for the day of the week and the week of the year. Standard errors, clustered at the individual leave, in in parentheses. $*, * *$, and $* * *$ indicate significance at $10 \%, 5 \%$, and $1 \%$ respectively. 
Appendix Table A3. Relationship between Proxy Income / Hours Targets and Need Amounts

(1)

Need amount (conditional on need)

Need amount (imputing as 0 days without a need)

Proxy Income Target
0.003
$(0.003)$

Observations

257

Number of bodas

0.04

0.15

$(2)$

t 0.003
$(0.003)$

34556

257

0.04

0.15
(3)

(4)

\begin{tabular}{cc}
\multicolumn{2}{c}{ Proxy Hours Target } \\
\hline 0.000 & \\
$(0.009)$ & 0.003 \\
& $(0.009)$ \\
30650 & 33879 \\
256 & 256 \\
0.03 & 0.03 \\
0.92 & 0.92 \\
\hline
\end{tabular}

Notes: These estimates follow Table 3 Crawford and Meng (2011). Targets are estimated as average daily income or hours on days up to but not including the day in question. Targets are estimated by day of the week. All regressions include individual fixed effects and controls for the week the day of week. Standard errors clustered at the individual level in parentheses. *, **, and *** indicate significance at 10\%, 5\%, and $1 \%$ respectively. 
Appendix Table A4. Cross-Sectional Returns to Education

\begin{tabular}{|c|c|c|c|c|c|c|c|c|c|c|c|c|c|c|}
\hline & (1) & (2) & (3) & (4) & (5) & (6) & (7) & (8) & (9) & (10) & (11) & (12) & (13) & (14) \\
\hline & \multicolumn{2}{|c|}{$\begin{array}{l}\text { Log average daily } \\
\text { income }\end{array}$} & \multicolumn{2}{|c|}{$\begin{array}{l}\text { Probability of } \\
\text { Working }\end{array}$} & \multicolumn{2}{|c|}{$\begin{array}{l}\text { Average Total } \\
\text { Hours }\end{array}$} & \multicolumn{2}{|c|}{$\begin{array}{l}\text { Average Number } \\
\text { of Passengers }\end{array}$} & \multicolumn{2}{|c|}{ Average Fare } & \multicolumn{2}{|c|}{ Average own wage rate } & \multicolumn{2}{|c|}{$\begin{array}{l}\text { Average local } \\
\text { wage rate }\end{array}$} \\
\hline \multirow[t]{2}{*}{ Years of Education } & 0.037 & 0.04 & 0.011 & 0.007 & -0.001 & -0.076 & 0.063 & 0.048 & 0.761 & 1.012 & 0.451 & 0.603 & 0.018 & -0.008 \\
\hline & $(0.010)^{* * *}$ & $(0.013)^{* * *}$ & $(0.009)$ & $(0.012)$ & $(0.053)$ & $(0.068)$ & $(0.034)^{*}$ & $(0.039)$ & $(0.400)^{*}$ & $(0.462)^{* *}$ & $(0.159)^{* * *}$ & $(0.201)^{* * *}$ & $(0.049)$ & $(0.017)$ \\
\hline \multirow[t]{2}{*}{ Age } & & -0.006 & & 0.002 & & -0.020 & & -0.009 & & 0.052 & & -0.113 & & -0.004 \\
\hline & & $(0.005)$ & & $(0.005)$ & & $(0.027)$ & & $(0.015)$ & & $(0.180)$ & & $(0.078)$ & & $(0.006)$ \\
\hline \multirow[t]{2}{*}{ Years of Experience } & & 0.009 & & -0.003 & & -0.014 & & -0.035 & & 0.734 & & 0.139 & & -0.004 \\
\hline & & $(0.007)$ & & $(0.007)$ & & $(0.037)$ & & $(0.022)$ & & $(0.253)^{* * *}$ & & $(0.109)$ & & $(0.009)$ \\
\hline \multirow[t]{2}{*}{ Married } & & 0.140 & & -0.068 & & 0.171 & & 0.387 & & -8.545 & & 0.717 & & -0.031 \\
\hline & & $(0.161)$ & & $(0.139)$ & & $(0.857)$ & & $(0.494)$ & & $(5.821)$ & & $(2.510)$ & & $(0.210)$ \\
\hline \multirow{2}{*}{ Number of children } & & 0.001 & & -0.005 & & 0.116 & & 0.054 & & -0.579 & & -0.082 & & 0.001 \\
\hline & & $(0.017)$ & & $(0.015)$ & & $(0.089)$ & & $(0.052)$ & & $(0.607)$ & & $(0.262)$ & & $(0.022)$ \\
\hline \multirow{2}{*}{$\begin{array}{l}\text { Log value of durable goods and } \\
\text { animals owned }\end{array}$} & & 0.036 & & -0.009 & & -0.192 & & -0.067 & & 2.236 & & 1.242 & & -0.011 \\
\hline & & $(0.043)$ & & $(0.039)$ & & $(0.231)$ & & $(0.133)$ & & $(1.567)$ & & $(0.681)^{*}$ & & $(0.056)$ \\
\hline \multirow[t]{2}{*}{ Acres of land owned } & & 0.005 & & 0.007 & & 0.050 & & 0.083 & & -1.065 & & 0.075 & & 0.050 \\
\hline & & $(0.024)$ & & $(0.022)$ & & $(0.129)$ & & $(0.074)$ & & $(0.876)$ & & $(0.378)$ & & $(0.032)$ \\
\hline \multirow[t]{2}{*}{ Self-reported health } & & -0.029 & & 0.047 & & -0.056 & & 0.012 & & -0.891 & & -0.184 & & -0.025 \\
\hline & & $(0.040)$ & & $(0.035)$ & & $(0.213)$ & & $(0.123)$ & & $(1.446)$ & & $(0.623)$ & & $(0.052)$ \\
\hline \multirow{2}{*}{$\begin{array}{l}\text { Missed work at least once in month } \\
\text { prior to baseline }\end{array}$} & & -0.169 & & -0.019 & & -0.254 & & -0.147 & & -5.121 & & -2.161 & & -0.081 \\
\hline & & $(0.063)^{* * *}$ & & $(0.058)$ & & $(0.338)$ & & $(0.195)$ & & $(2.297)^{* *}$ & & $(0.991)^{* *}$ & & $(0.083)$ \\
\hline \multirow[t]{2}{*}{ Has a bank account } & & 0.004 & & -0.024 & & -0.226 & & -0.223 & & 5.119 & & 0.806 & & 0.127 \\
\hline & & $(0.064)$ & & $(0.059)$ & & $(0.341)$ & & $(0.197)$ & & $(2.317)^{* *}$ & & $(1.001)$ & & $(0.083)$ \\
\hline Observations (individual-days) & 257 & 256 & 232 & 231 & 257 & 256 & 257 & 256 & 257 & 256 & 256 & 255 & 257 & 256 \\
\hline R-squared & 0.05 & 0.21 & 0.01 & 0.23 & 0.00 & 0.20 & 0.01 & 0.37 & 0.01 & 0.36 & 0.03 & 0.25 & 0.00 & 0.94 \\
\hline Mean of Dep. Var. & -2.33 & -2.33 & 0.85 & 0.85 & 6.55 & 6.55 & 3.27 & 3.26 & 35.63 & 35.64 & 17.34 & 17.33 & 17.20 & 17.19 \\
\hline Std. Dev. of Dep. Var & 0.42 & 0.42 & 0.36 & 0.36 & 2.22 & 2.23 & 1.44 & 1.44 & 16.87 & 16.90 & 6.70 & 6.71 & 2.04 & 2.03 \\
\hline
\end{tabular}




\section{Appendix Figure A1. Proxying Target with Average Past Realized Income/Hours on same Week Day}

\section{Panel A. Income}

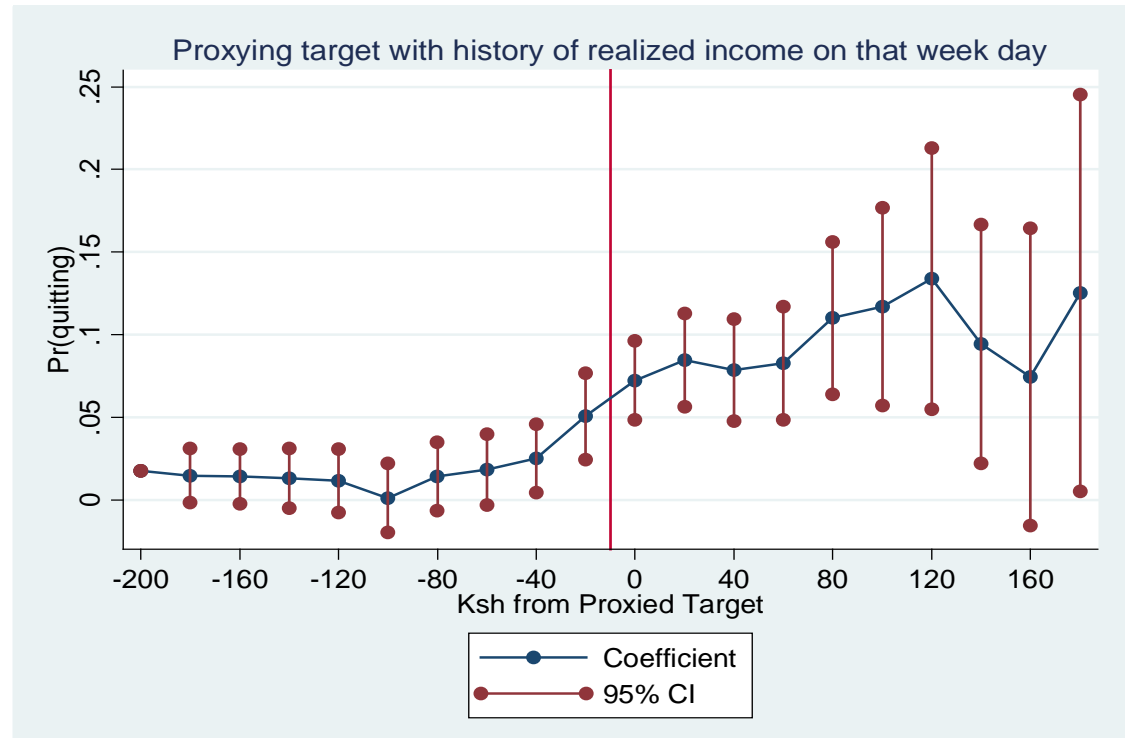

Panel B. Hours

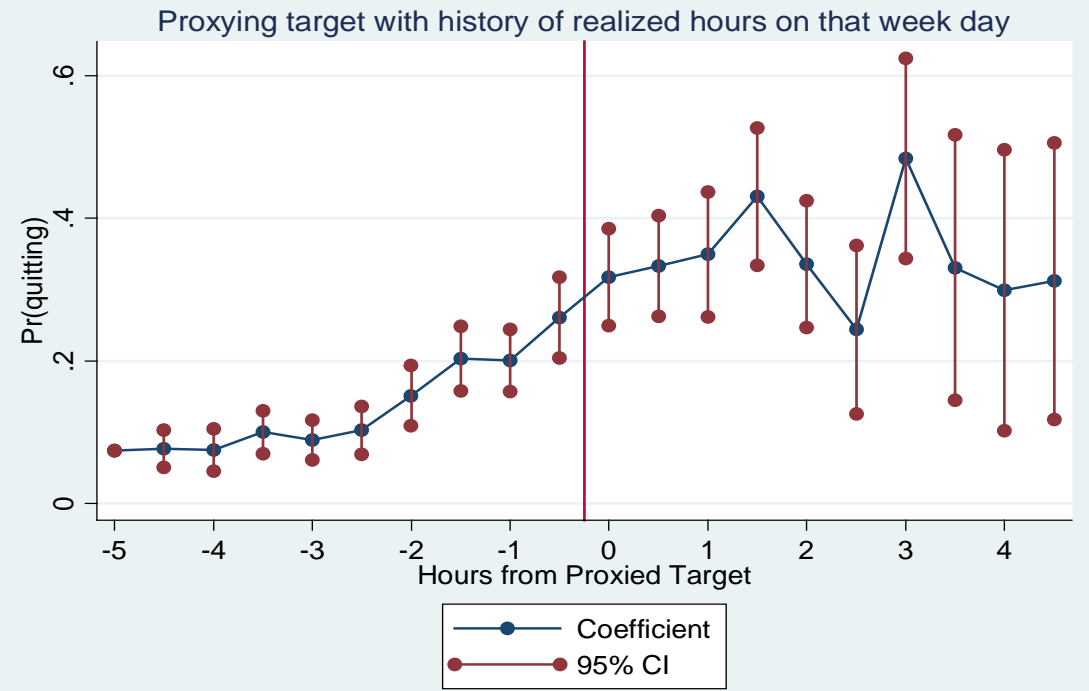

Notes: These estimates follow Crawford and Meng (2011). Proxy targets are estimated as average daily income or hours on days up to but not including the day in question. Proxy targets are estimated by day of the week. 
Appendix Figure A2. Education, Income, and Work Intensity
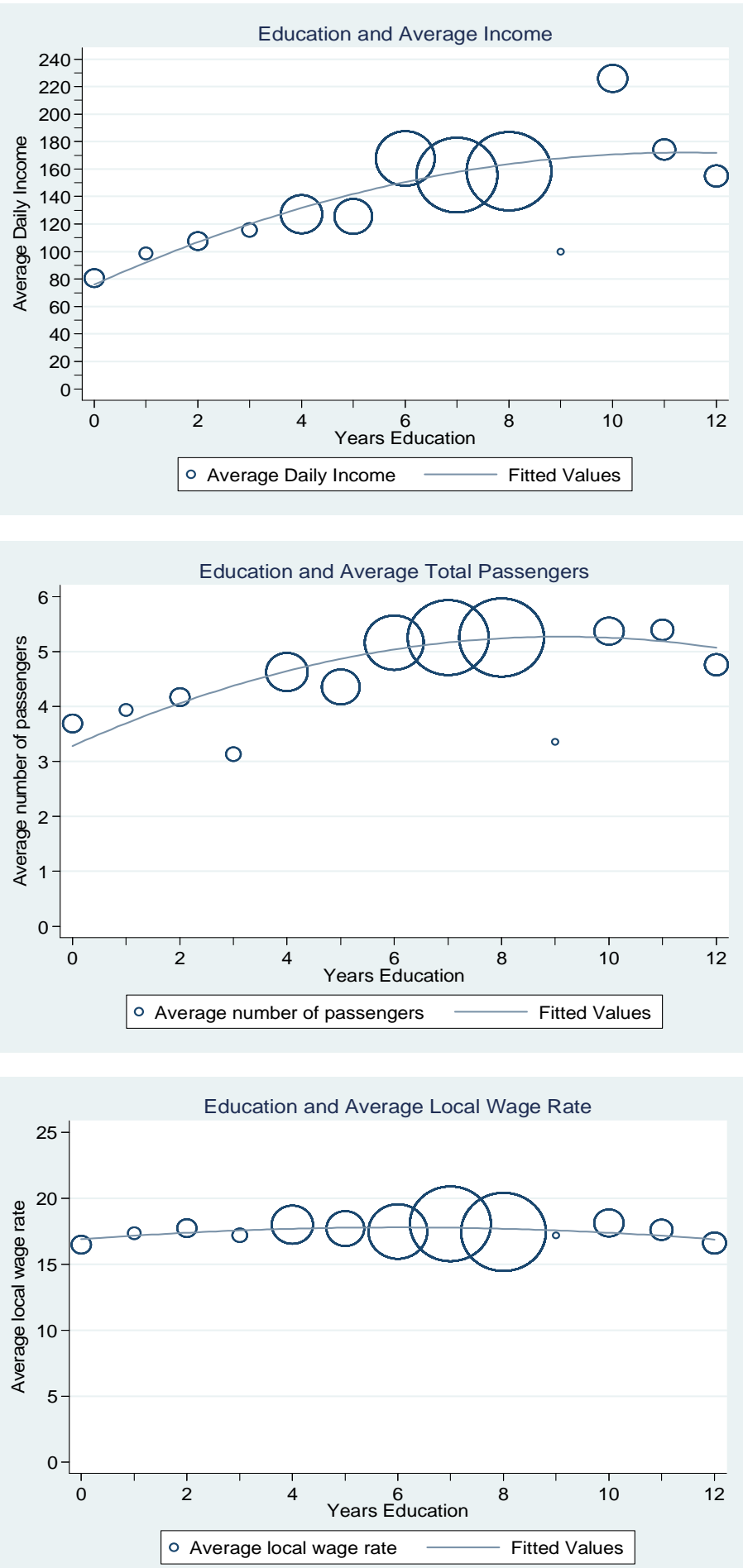
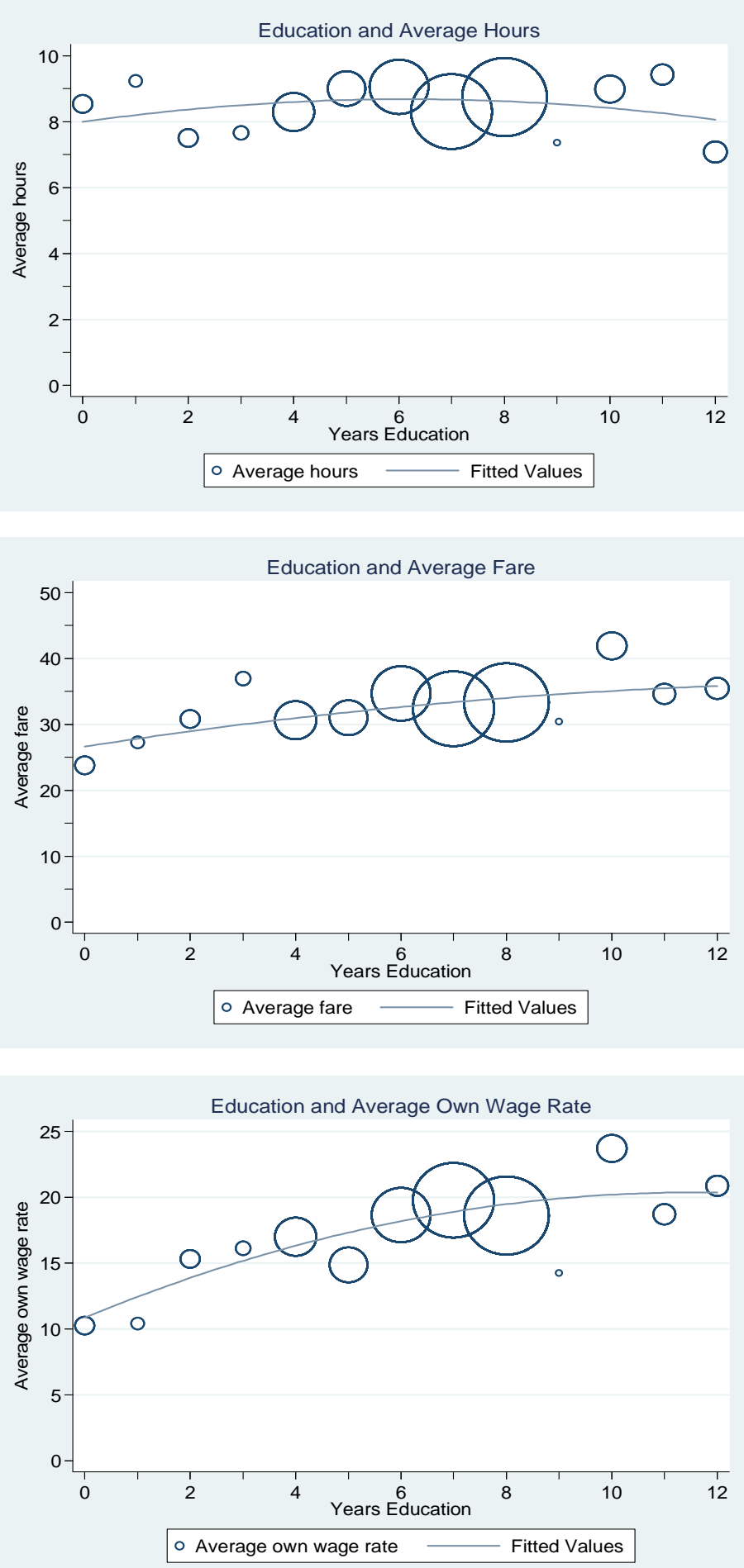

46 
Appendix Figure A3. Hazard Regressions: Further Heterogeneity Analyses
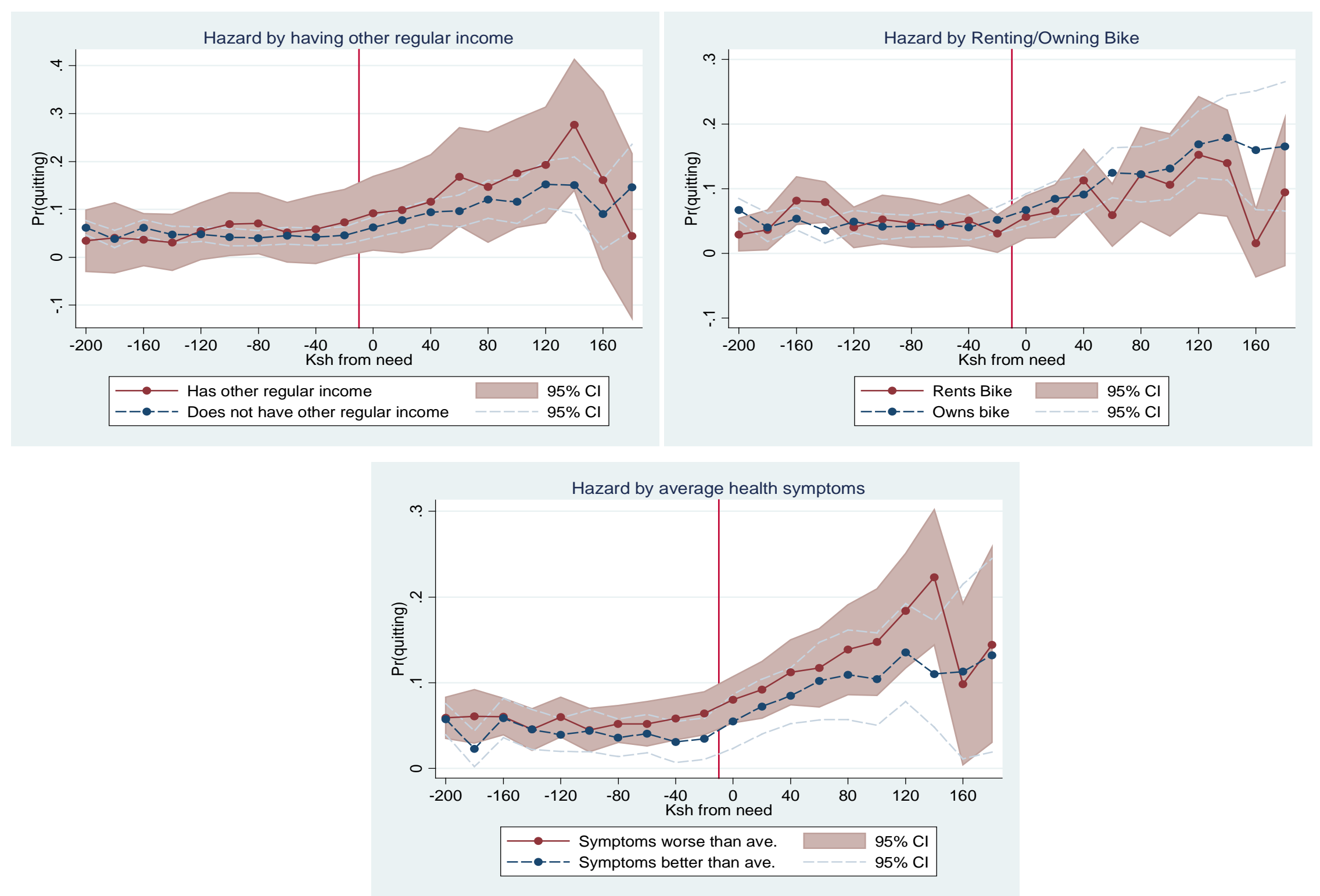